\title{
Sol-gel derived bioactive glasses with low tendency to crystallize: Synthesis, post-sintering bioactivity and possible application for the production of porous scaffolds
}

\author{
Devis Bellucci $^{\text {a,* }}{ }^{\text {, Antonella Sola }}{ }^{\text {a }}$, Roberta Salvatori ${ }^{\text {b }}$, Alexandre Anesi ${ }^{\text {b }}$, Luigi Chiarini ${ }^{\text {b }}$, Valeria Cannillo ${ }^{\text {a }}$ \\ a Department of Engineering “E. Ferrari”, University of Modena and Reggio Emilia, Via Vignolese 905, 41125 Modena, Italy \\ b Lab. Biomaterials, Department of Medical and Surgical Sciences of Children E Adults, University of Modena and Reggio Emilia, Via Campi 213/A, 41125 Modena, Italy
}

\section{A R T I C L E I N F O}

\section{Article history:}

Received 27 August 2013

Received in revised form 30 May 2014

Accepted 13 July 2014

Available online 19 July 2014

\section{Keywords:}

Sol-gel

Bioactive glasses

Scaffolds

Sintering

Bone tissue engineering

\begin{abstract}
A B S T R A C T
A new sol-gel (SG) method is proposed to produce special bioactive glasses (BG_Ca family) characterized by a low tendency to devitrify. These formulations, derived from $45 \mathrm{~S} 5$ Bioglass $\AA$, are characterized by a high content of $\mathrm{CaO}$ ( $45.6 \mathrm{~mol} \%$ ) and by a partial or complete substitution of sodium oxide with potassium oxide (total amount of alkaline oxides: $4.6 \mathrm{~mol} \%$ ), which increases the crystallization temperature up to $900{ }^{\circ} \mathrm{C}$. In this way, it is possible to produce them by SG preserving their amorphous nature, in spite of the calcination at $850{ }^{\circ} \mathrm{C}$. The sintering behavior of the obtained SG powders is thoroughly investigated and the properties of the sintered bodies are compared to those of the melt-derived (M) counterparts. Furthermore, the SG glass powders are successfully used to produce scaffolds by means of a modified replication technique based on the combined use of polyurethane sponges and polyethylene particles. Finally, in the view of a potential application for bone tissue engineering, the cytotoxicity of the produced materials is evaluated in vitro.
\end{abstract}

(c) 2014 Elsevier B.V. All rights reserved.

\section{Introduction}

At the beginning of the '70s, Hench et al. were the first authors to document that some glasses in the $\mathrm{Na}_{2} \mathrm{O}-\mathrm{CaO}-\mathrm{P}_{2} \mathrm{O}_{5}-\mathrm{SiO}_{2}$ system can form a strong interfacial bond with bone tissue [1]. This property is imputable to the development on their surface, when they are in contact with biological fluids, of a hydroxycarbonated apatite (HCA) layer, which is analogue to the mineral phase of bones. Later works also demonstrated that specific bioactive glasses can even bond with soft tissue through the attachment of collagen to their surface [2]. More recently, it has been reported that bioactive glasses influence the cellular behavior and the production of extra-cellular matrix through their surface chemistry, topography and, in particular, their ionic dissolution products [3-5]. Historically, the most important glass in the $\mathrm{Na}_{2} \mathrm{O}-\mathrm{CaO}-$ $\mathrm{P}_{2} \mathrm{O}_{5}-\mathrm{SiO}_{2}$ system is the so-called $45 \mathrm{~S} 5$ Bioglass $®$, which has been used in a number of clinical applications in the orthopedic and dental field since the mid-1980s.

Bioactive glasses are often prepared by conventional melting (M) methods, i.e. by heating the precursor mixture of raw materials and then quenching the molten liquid to form a glass. In the last years, however, many efforts have been focused on the fabrication of bioactive glasses by means of the sol-gel (SG) technique, which was proposed in the early '70s as a promising and particularly versatile alternative route

\footnotetext{
* Corresponding author. Tel.: + 39059 2056233; fax: + 390592056243.

E-mail address: devis.bellucci@unimore.it (D. Bellucci).
}

to synthesize glasses [6,7]. The SG method offers several advantages with respect to the conventional melting technique. First of all, it makes it possible to obtain extremely fine (sub-micrometric) powders, with a very controlled composition. Then it requires relatively low processing temperatures and allows for the production of glasses with higher homogeneity and purity than those obtained by the traditional melting/cooling route [6,7]. Moreover SG glasses are bioactive in a wider range of compositions than conventional melt-derived ones, mainly thanks to their higher porosity, which results in a larger specific surface area and, hence, in a superior dissolution rate [8-11]. In particular, if the $\mathrm{Na}_{2} \mathrm{O}-\mathrm{CaO}-\mathrm{P}_{2} \mathrm{O}_{5}-\mathrm{SiO}_{2}$ system is considered, it is reported that $\mathrm{M}$ bioglasses with more than $60 \mathrm{~mol} \% \mathrm{SiO}_{2}$ are biologically inactive [10]; on the contrary, SG glasses with $85 \mathrm{~mol} \% \mathrm{SiO}_{2}$ maintain their bioactive behavior. At the same time, the composition of SG glasses can be varied over wide ranges, thus providing the possibility to investigate the biological effect of different organic and inorganic dopants, such as $\mathrm{Sr}, \mathrm{Zn}$, $\mathrm{Ag}$, Mg, and Sm, in order to develop new formulations tailored for specific applications [12-15]. Finally, as stressed by Hench [4], the SG processing helps to control the ion dissolution rates from bioglasses in physiological solutions. Nonetheless, most of the SG bioactive glasses reported in literature are binary or ternary systems which include only $\mathrm{SiO}_{2}, \mathrm{CaO}$ and $\mathrm{P}_{2} \mathrm{O}_{5}$, but not alkaline oxides such as $\mathrm{Na}_{2} \mathrm{O}$. This is due to the high hydrolytic reactivity of sodium alkoxide (the ordinary $\mathrm{SG}$ precursor for $\mathrm{Na}_{2} \mathrm{O}$ ), which makes the production of $\mathrm{Na}_{2} \mathrm{O}-\mathrm{CaO}-$ $\mathrm{P}_{2} \mathrm{O}_{5}-\mathrm{SiO}_{2}$ glasses a demanding task from a technological point of view. Since alkaline oxides play a key role in the biological performance 
of bioactive glasses $[16,17]$ and since the $45 S 5$ Bioglass ${ }^{\circledR}$, which also includes $\mathrm{Na}_{2} \mathrm{O}$, is recognized as the "gold" standard for bioactive glasses, the production and assessment of quaternary glasses by means of the SG method are fundamental issues [18]. In consequence, some protocols aiming to incorporate $\mathrm{Na}_{2} \mathrm{O}$ into $\mathrm{SG}$ glasses synthesized under ambient conditions have been attempted. In 2010 Chen et al. obtained fine powders of SG 45S5 glass-ceramic employing $\mathrm{NaNO}_{3}$ as precursor for $\mathrm{Na}_{2} \mathrm{O}$ [19]. One year later, the same authors also presented simple SG $45 S 5$ ceramic foams, produced by means of the addition of a surfactant combined with mechanical stirring and subsequent sintering. However, the microstructure of these prototypal scaffolds was not satisfactory due to their almost closed porosity which prevents cell infiltration [17]. A systematic study on the compositional, microstructural and sintering behavior of SG $45 \mathrm{~S} 5$ has been attempted very recently by Cacciotti et al. [20], while Siqueira and co-workers produced bioactive ceramic powders of the quaternary $\mathrm{Na}_{2} \mathrm{O}-\mathrm{CaO}-\mathrm{P}_{2} \mathrm{O}_{5}-\mathrm{SiO}_{2}$ system, choosing $\mathrm{NaNO}_{3}$ as precursor for $\mathrm{Na}_{2} \mathrm{O}$ and testing triethylphosphate and phosphoric acid as precursors for $\mathrm{P}_{2} \mathrm{O}_{5}$ [21]. The main drawback of these protocols is that the full thermal decomposition of $\mathrm{NaNO}_{3}$ occurs at about $680{ }^{\circ} \mathrm{C}[22]$, while the crystallization temperature of $45 \mathrm{~S} 5$ is about $600{ }^{\circ} \mathrm{C}[23,24]$. For this reason, the heat treatment converts the gel into a ceramic powder (mainly $\mathrm{Na}_{2} \mathrm{Ca}_{2} \mathrm{Si}_{3} \mathrm{O}_{9}$ and $\mathrm{Na}_{2} \mathrm{Ca}_{3} \mathrm{Si}_{6-}$ $\mathrm{O}_{16}$ ) instead of a glass. Unfortunately, although the crystallization may improve the mechanical properties of the fully dense bodies, it may also limit their bioactivity, since the newly formed crystal phases are scarcely bioactive compared to the starting glass [24-30].

In order to limit the tendency to crystallize with respect to $45 \mathrm{~S} 5$, alternative bioactive glasses belonging to the $\mathrm{Na}_{2} \mathrm{O}-\mathrm{CaO}-\mathrm{P}_{2} \mathrm{O}_{5}-\mathrm{SiO}_{2}$ family have been recently proposed. The first composition, named BG_Ca, was characterized by a relatively high $\mathrm{CaO}-$ to- $\mathrm{Na}_{2} \mathrm{O}$ ratio (BG_Ca composition in mol\%: $4.6 \mathrm{Na}_{2} \mathrm{O}$; $45.6 \mathrm{CaO} ; 2.6 \mathrm{P}_{2} \mathrm{O}_{5} ; 47.2 \mathrm{SiO}_{2}$ ) and it was successfully employed for the fabrication of hydroxyapatite-based biocomposites [31-33]. Subsequently, in order to further improve the thermal stability of the glass, two novel glasses were developed from the original BG_Ca formulation, with a partial (BG_Ca/Mix) or complete (BG_Ca/K) substitution of sodium oxide with potassium oxide (BG_Ca/ Mix composition in mol\%: $2.3 \mathrm{Na}_{2} \mathrm{O} ; 2.3 \mathrm{~K}_{2} \mathrm{O} ; 45.6 \mathrm{CaO} ; 2.6 \mathrm{P}_{2} \mathrm{O}_{5} ; 47.2$ $\mathrm{SiO}_{2} ; \mathrm{BG} \_\mathrm{Ca} / \mathrm{K}$ composition in mol\%: $4.6 \mathrm{~K}_{2} \mathrm{O} ; 45.6 \mathrm{CaO} ; 2.6 \mathrm{P}_{2} \mathrm{O}_{5} ; 47.2$ $\mathrm{SiO}_{2}$ ) [34,35]. All these glasses have been produced so far by the conventional melt-quenching technique, but their extremely high crystallization temperature (about $880{ }^{\circ} \mathrm{C}$ for BG_Ca/Mix and $920{ }^{\circ} \mathrm{C}$ for BG_Ca/ $\mathrm{K}[34]$ ) opens the intriguing possibility to produce them by SG and to preserve their amorphous character. So the present contribution proposes a new protocol to produce the BG_Ca, BG_Ca/Mix and BG_Ca/K glasses by means of the SG method. According to the original work by Chen et al., $\mathrm{NaNO}_{3}$ was used to introduce $\mathrm{Na}_{2} \mathrm{O}$ [17]; instead, $\mathrm{KNO}_{3}$ was employed as precursor for $\mathrm{K}_{2} \mathrm{O}$ in the $\mathrm{BG} \_\mathrm{Ca} / \mathrm{Mix}$ and $\mathrm{BG} \_\mathrm{Ca} / \mathrm{K}$ glasses. Moreover, the sintering behavior of the obtained powders and the thermal evolution of their crystalline phases were carefully analyzed. The microstructure and related properties of the SG sintered bodies were investigated and compared to those of the M counterparts. Particular attention was paid to their bioactivity, which was preliminary assessed in vitro by means of the procedure proposed by Kokubo and Takadama [36]. Cytotoxicity tests based on in vitro cell culture were also performed in order to evaluate the biocompatibility of the produced materials. To conclude, the feasibility of SG glass-derived scaffolds was assessed.

\section{Materials and methods}

\subsection{Sol-gel synthesis}

The BG_Ca, BG_Ca/Mix and BG_Ca/K glasses $[33,34]$ were synthesized by hydrolysis and polycondensation of stoichiometric amounts of tetraethyl orthosilicate (TEOS, $\mathrm{Si}\left(\mathrm{OC}_{2} \mathrm{H}_{5}\right)_{4}$, Sigma Aldrich), triethylphosphate (TEP, $\mathrm{OP}\left(\mathrm{C}_{2} \mathrm{H}_{5} \mathrm{O}\right)_{3}$, Sigma Aldrich) and calcium nitrate tetrahydrate $\left(\mathrm{Ca}\left(\mathrm{NO}_{3}\right)_{2} \cdot 4 \mathrm{H}_{2} \mathrm{O}\right.$, Sigma Aldrich); in addition to these common precursors, sodium nitrate $\left(\mathrm{NaNO}_{3}\right.$, Carlo Erba Reagenti, Italy) was added to prepare BG_Ca and BG_Ca/Mix, while potassium nitrate $\left(\mathrm{KNO}_{3}\right.$, Carlo Erba Reagenti, Italy) was added for BG_Ca/Mix and BG_Ca/K. A flowchart of the steps followed to prepare the gel powders and to induce their subsequent conversion into glass (or glass-ceramic, depending on the gel formulation) is reported in Fig. 1. Starting with the hydrolysis of TEOS, each chemical was consecutively added into a $\mathrm{HNO}_{3}$ (Carlo Erba Reagenti, Italy) aqueous solution $(0.1 \mathrm{M})$ at 30 -minute intervals under continuous magnetic stirring and only when the solution had become completely clear. The process was performed at room temperature. After adding the last chemical, the resultant solution was maintained at room temperature for $4 \mathrm{~h}$ without stirring and then stored at $35^{\circ} \mathrm{C}$ for three days. Subsequently, the gels were dried for six days at $50{ }^{\circ} \mathrm{C}$ and for three more days at $110{ }^{\circ} \mathrm{C}$. At the end of the drying step, the gels were ball-milled in a ceramic jar and sieved to a final grain size below $68 \mu \mathrm{m}$. For the sake of clarity, in the following discussion, the dried, milled and sieved gels will be referred to as "asdried gel powders".

The as-dried gel powders were converted into glass/glass-ceramic powders by heat-treating them in an electric furnace. The specific heating programs were defined according to the results of the differential thermal analysis (DTA) and thermo-gravimetric (TG) analysis performed on the as-dried gel powders, as reported more in detail in the next paragraphs. So the as-dried gel powders were calcined at different temperatures (i.e. $700{ }^{\circ} \mathrm{C}, 800{ }^{\circ} \mathrm{C}, 850{ }^{\circ} \mathrm{C}, 900{ }^{\circ} \mathrm{C}, 1000{ }^{\circ} \mathrm{C}$ ) with $5^{\circ} \mathrm{C} / \mathrm{min}$ heating rate and $1 \mathrm{~h}$ dwelling time.

\subsection{Preparation of glass powders by melting}

The BG_Ca, BG_Ca/Mix and BG_Ca/K glasses were also produced by means of the conventional melt-quenching technique $(\mathrm{M})$, i.e. by melting the raw powders $\left(\mathrm{SiO}_{2}, \mathrm{Ca}_{3}\left(\mathrm{PO}_{4}\right)_{2}, \mathrm{CaCO}_{3}, \mathrm{Na}_{2} \mathrm{CO}_{3}\right.$ and/or $\mathrm{K}_{2} \mathrm{CO}_{3}$ by Carlo Erba Reagenti, Italy) in a platinum crucible at $1450{ }^{\circ} \mathrm{C}$, as reported in $[33,34]$. The melt was quenched in water to obtain a frit, which was ground in a porcelain jar and then sieved below $68 \mu \mathrm{m}$. For comparison purposes, part of the $\mathrm{M}$ powders (named heat-treated-M) were thermally treated at different temperatures (i.e. $700{ }^{\circ} \mathrm{C}, 800{ }^{\circ} \mathrm{C}, 850{ }^{\circ} \mathrm{C}$, $900{ }^{\circ} \mathrm{C}, 1000{ }^{\circ} \mathrm{C}$ ) with a heating rate of $5{ }^{\circ} \mathrm{C} / \mathrm{min}$ and $1 \mathrm{~h}$ dwelling time, according to the same schedules used for the calcination of the SG counterparts.

\subsection{Powder characterization}

The thermal behavior of the as-dried gel powders was investigated by means of simultaneous thermogravimetry, TG, and differential thermal analysis, DTA (NETZSCH DSC-TG 409, NETZSCH-Gerätebau GmbH, Selb, Germany). The powders were heated from room temperature to $1200{ }^{\circ} \mathrm{C}$ with a heating rate of $10{ }^{\circ} \mathrm{C} / \mathrm{min}$.

In order to analyze the possible heat-induced crystallization phenomena X-ray diffraction (XRD) analyses (X'Pert PRO, PANalytical, Almelo, The Netherlands) were performed on the as-dried gel powders and on the $\mathrm{M}$ powders, before and after heat-treatment at different temperatures (i.e. $700{ }^{\circ} \mathrm{C}, 800{ }^{\circ} \mathrm{C}, 850{ }^{\circ} \mathrm{C}, 900{ }^{\circ} \mathrm{C}, 1000{ }^{\circ} \mathrm{C}$, as previously mentioned). $\mathrm{Cu} \mathrm{k} \alpha$ radiation in the $10^{\circ}-70^{\circ} 2 \theta$ angular range, with steps of $0.017^{\circ}$ and a scanning rate of $0.02^{\circ} \mathrm{s}^{-1}$, was employed. The powders were also observed in an Environmental Scanning Electron Microscope (ESEM Quanta 2000, FEI Co., Eindhoven, The Netherland). The SEM was operated in low-vacuum mode with a pressure of 0.53 Torr. Qualitative compositional analyses were performed by means of X-ray energy dispersion spectroscopy (EDS) (Inca, Oxford Instruments, UK). In the following, both the XRD and the ESEM facility will be employed in the abovementioned configuration without any further specification. 


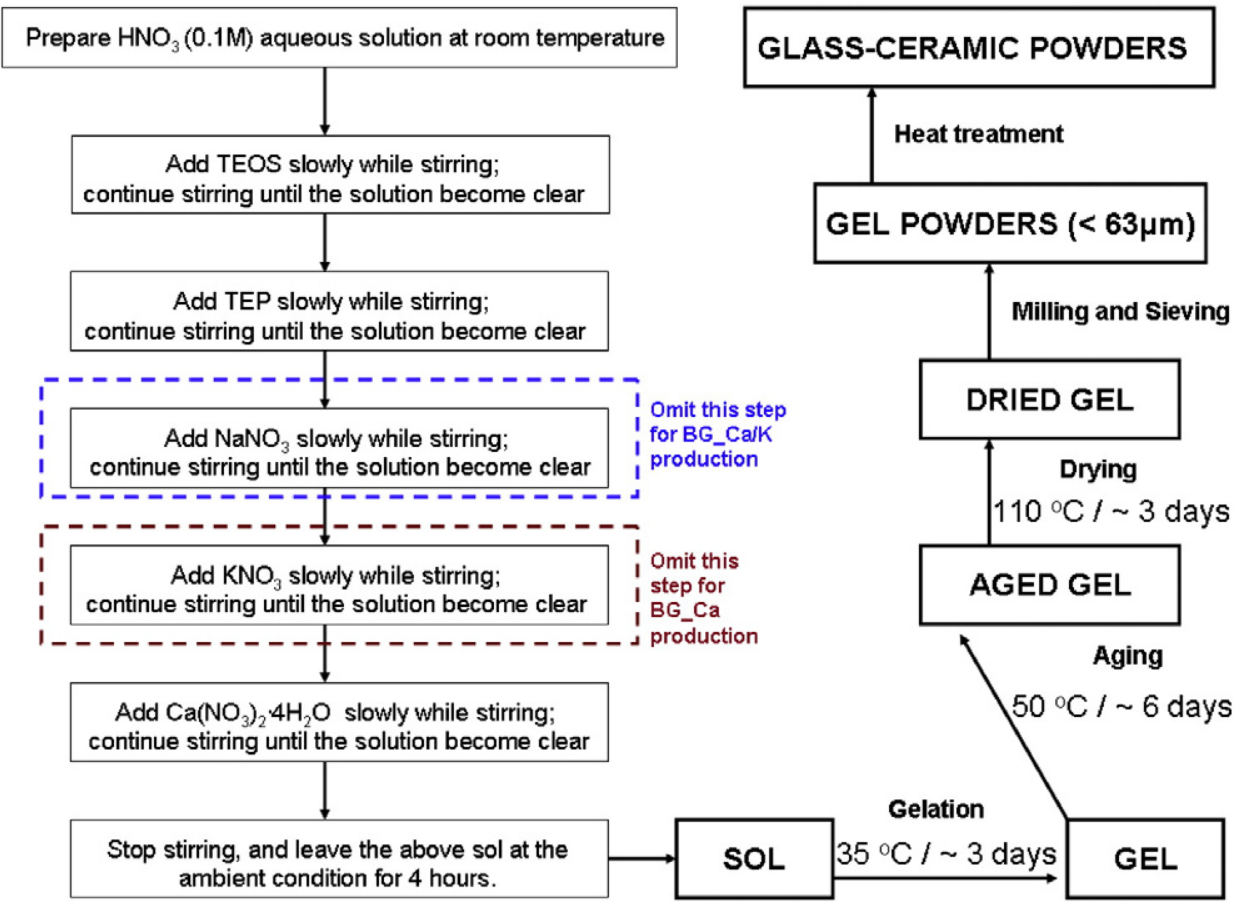

Fig. 1. Flowchart of the production process.

\subsection{Sintering behavior and characterization of dense bodies}

As described in the following "Results and discussion" section, taking into account the results of DTA, EDS and X-ray diffraction, only SG powders calcined at $850{ }^{\circ} \mathrm{C}$ for $1 \mathrm{~h}$ were chosen for further investigations. Therefore, the label "SG" will henceforth indicate these powders without further specifications. The sintering behavior of the SG powders was evaluated by means of an optical dilatometer (Misura 3.32; Expert System Solutions, Modena, Italy). The test was performed on $5 \times 5 \times 15 \mathrm{~mm}^{3}$ samples of pressed powder treated from room temperature to $1000{ }^{\circ} \mathrm{C}$ at $10{ }^{\circ} \mathrm{C} / \mathrm{min}$. According to the dilatometric tests, the best sintering temperature, which corresponds to the maximum contraction rate, is about $\mathrm{T}_{\text {sint }}=800{ }^{\circ} \mathrm{C}$ for $\mathrm{SG}$ BG_Ca, SG BG_Ca/Mix and SG BG_Ca/K. Therefore, the powders were mixed for $6 \mathrm{~h}$, wetted with $10 \mathrm{wt}$.\% of acetone and subsequently pressed at $60 \mathrm{MPa}$ for $15 \mathrm{~s}$ in order to obtain $15 \mathrm{~mm}$-diameter disks (green bodies). The green bodies were then sintered at $\mathrm{T}_{\text {sint }}$ for $3 \mathrm{~h}$ (heating rates of $5{ }^{\circ} \mathrm{C} / \mathrm{min}$ from room temperature to $500{ }^{\circ} \mathrm{C}$ and of $10{ }^{\circ} \mathrm{C} / \mathrm{min}$ from $500{ }^{\circ} \mathrm{C}$ to $800{ }^{\circ} \mathrm{C}$ ) in order to obtain SG BG_Ca, SG BG_Ca/Mix and SG BG_Ca/K dense bodies. According to preliminary tests (data not shown), the duration of the sintering isotherm $(3 \mathrm{~h}$ at $800{ }^{\circ} \mathrm{C}$ ) was chosen to achieve a complete densification. For comparison purposes, M BG_Ca, M BG_Ca/Mix and M BG_Ca/K powders were processed in the same way to prepare green bodies and then they were sintered at the same temperature $\mathrm{T}_{\text {sint }}=800{ }^{\circ} \mathrm{C}$. Indeed it is worth noting that, according to previous investigations, such temperature is also appropriate to obtain dense sintered body starting from melt-derived powders of the BG_Ca family $[33,34]$.

The shrinkage (in percent), $\Delta \%$ due to the densification process was calculated according to the following equation:

$\Delta_{\%}=\frac{d_{0}-d_{\exp }}{d_{0}} \cdot 100$

where $d_{0}$ is the nominal diameter of the mold of the press $(15 \mathrm{~mm})$ and $d_{\text {exp }}$ is the diameter of the sample after heat treatment (experimentally measured). For each SG and M powder five samples were considered and mean values were calculated.

As already done for the loose powders, an XRD was performed on the SG and M sintered bodies aiming to study the heat-induced development of crystalline phases possibly occurred as a result of the sintering process. The microstructure of the surface of the samples and of their polished cross-section was investigated with an ESEM.

\subsection{Scaffold preparation and characterization}

In this feasibility study only SG BG_Ca/K powders were considered for the production of scaffolds. In particular, the SG BG_Ca/K powders were used to fabricate a new kind of scaffolds, called "shell scaffolds". The name derives from the peculiar morphology of such scaffolds, which combines a foam-like internal structure with a very robust (but still porous) external surface, i.e. the "shell" [37,38]. The procedure to manufacture bioceramic shell scaffolds is just summarized here, since it has been recently described in detail elsewhere [37, 38]. First of all, ceramic slurries were prepared with $32 \mathrm{wt} . \%$ SG BG_Ca/K powders, 6 wt.\% polyvinyl alcohol (PVA), 5 wt.\% polyethylene powder and $57 \mathrm{wt} . \%$ distilled water. The addition of polyethylene particles helps to control the final porosity, especially at the outer surface, where the burning-out of the particles during the heat treatment is expected to result in large pores, which are able to favor an adequate cell infiltration. Commercial polyurethane sponges [39], which act as organic templates for scaffolds, were then immersed in the slurry, extracted without squeezing and immediately dried in a multidirectional air flux in order to obtain green bodies. In this sense, as pointed out in Refs. [37,38], such procedure completely differs from the traditional foam replication method, where

- Polyethylene powders are not involved;

- Sponges after soaking are squeezed and then dried very slowly.

The green bodies were heat-treated at $\mathrm{T}_{\text {sint }}=800{ }^{\circ} \mathrm{C}$ for $3 \mathrm{~h}$ in a ventilated kiln in order to remove the organic template and the polyethylene particles, and to sinter the ceramic phase. 
The obtained scaffolds were investigated with an ESEM. The total pore content of the scaffolds was calculated by means of the following equation

$P_{\%}=\left(1-\frac{W_{f}}{W_{t}}\right) \times 100$

where $W_{f}$ stands for the measured weight of the sample and $W_{t}$ stands for the theoretical one, which can be calculated by multiplying the scaffold volume by the glass theoretical density. The scaffold total porosity was also estimated by means of image analysis, as an alternative route. To this aim, an open-source software (ImageJ, see http:// rsbweb.nih.gov/ij/) was employed and five different samples were considered. According to the protocol described in Refs. [40,41], capillarity tests were carried on with the aim to qualitatively evaluate the permeability of the produced scaffolds and the presence of an interconnected pores network. For this purpose, the samples were put in contact with a solution with a viscosity similar to physiological fluids [40,41]. Blue ink drops were dispersed into the solution to highlight the fluid adsorption through the scaffold's porosity due to capillarity forces. The samples were finally cut in two pieces in order to verify the solution up-take in their inner part.

Even if the present contribution explores only the feasibility of scaffolds derived from sol-gel calcined powders and the detailed characterization is deferred to a specific future contribution, a preliminary mechanical test was performed on the scaffolds produced (at $800{ }^{\circ} \mathrm{C}$ ) with the SG BG_Ca/K powders. Compression tests were carried out on $1 \mathrm{~cm} \times 1 \mathrm{~cm} \times 1 \mathrm{~cm}$ cubic samples using a Zwick Roell Z600; the instrument was equipped with an automatic highresolution digital measurement system by the same Zwick Roell. The crosshead speed was fixed at $0.01 \mathrm{~mm} / \mathrm{min}$ and the stressdeformation curve was monitored until densification of the porous samples started to occur. The scaffold yield strength was defined as the ratio between the maximum applied load and the cross sectional area of the sample. Five samples were considered to have reliable data.

\subsection{Evaluation of in vitro bioactivity in $\mathrm{SBF}$}

The bioreactivity of the obtained samples (SG BG_Ca, SG BG_Ca/Mix and SG BG_Ca/K fully dense bodies, fired at $800{ }^{\circ} \mathrm{C}$ for $3 \mathrm{~h}$, and SG BG_Ca/K shell scaffolds, also treated at $800{ }^{\circ} \mathrm{C}$ for $3 \mathrm{~h}$ ) was evaluated in vitro in a Simulated Body Fluid (SBF) solution, as outlined by Kokubo et al. [36,42]. The samples were kept in closed flasks, each containing $25 \mathrm{ml}$ of SBF. The flasks were maintained at $37{ }^{\circ} \mathrm{C}$ and the solution was refreshed three times a week (after 2, 4, 7, 9, 11 days) to reproduce dynamic conditions. The $\mathrm{pH}$ variation induced by the samples was monitored. After 3, 7 and 14 days in SBF, the samples were extracted, rinsed in distilled water and left to dry at ambient conditions before further characterization.

The changes occurred on the surface and the formation of an apatite layer was monitored by X-ray diffraction and by direct observation in a scanning electron microscope. Moreover, cross-sectional images were acquired on cut and polished samples, previously mounted in resin, in order to evaluate the thickness of the precipitates as a function of time in SBF.

Micro-Raman spectroscopy was also performed on the samples in order to investigate the chemical nature of the precipitated apatite. A Jobin-Yvon Raman Microscope spectrometer (Horiba Jobin-Yvon, Villeneuve d'Ascq, France) was employed (632.8 nm-wavelength He-Ne diode laser emitting; output power of $20 \mathrm{~mW}$ at the sample). The laser beam was focused on the surface of the samples by means of $50 \times$ and $100 \times$ objectives. A spectrum collection setup of 15 acquisitions, each of them taking $40 \mathrm{~s}$, was used.

\subsection{Cytotoxicity tests}

The cytotoxicity of the SG sintered samples was evaluated in vitro with BALB/3T3 (mouse embryonic fibroblast cell line) cells, according to International Standard prescriptions $[43,44]$. The survival/viability of the cells was assessed by means of Neutral Red (NR) uptake and XTT assays.

\subsubsection{Culture of BALB/3T3 cells and preparation of materials' extracts}

BALB/3T3 cells were cultured in Dulbecco's modified Eagle's medium (DMEM) (Invitrogen, Karlsruhe, Germany), supplemented with $10 \%$ fetal bovine serum (Invitrogen), L-Glutamine $2 \mathrm{mM}$ and sodium pyruvate $1 \mathrm{mM}$ (Invitrogen) and $100 \mu \mathrm{g} / \mathrm{ml}$ pen-streptomycin (Invitrogen) on 6 well plates for direct contact with the samples dishes and the Neutral Red assay procedure was carried on (see next paragraph). The cells were maintained in a $5 \% \mathrm{CO}_{2}$ humidified incubator at $37{ }^{\circ} \mathrm{C}$ and subcultured approximately for $72 \mathrm{~h}$.

The extracts of the BG_Ca, BG_Ca/Mix and BG_Ca/K sintered glasses were obtained by treating them in centrifuge tubes, $6 \mathrm{~cm}^{2} / \mathrm{ml}$ area each containing DMEM. A vial with $6 \mathrm{ml}$ of DMEM only was employed as negative control (CTRL - ), while DMEM with $0.45 \%$ of phenol solution was used as positive reference $(\mathrm{CTRL}+)$. Vials were incubated at $37^{\circ} \mathrm{C}$ for 5 days and $\mathrm{pH}$ was periodically measured in order to maintain physiological conditions. Every extract was then filtered by means of a $0.22 \mu \mathrm{m}$ filter before cytotoxicity tests $[43,44]$.

\subsubsection{NR and XTT tests}

The Neutral Red uptake (Neutral Red solution N6264 Sigma, Germany) test is a sensitive and widely used assay to estimate the number of viable cells in a culture. It is based on the ability of viable cells to accumulate intracellularly the supravital dye neutral red within their lysosomes [45]. Cytotoxicity is expressed as a reduction of the NR uptake after one day ( $\sim 1$ doubling period) of chemical exposure to the test material.

BALB/3T3 cells were seeded and cultured at $37{ }^{\circ} \mathrm{C} \pm 1{ }^{\circ} \mathrm{C}, 5.0 \% \pm 1 \%$ $\mathrm{CO}_{2} /$ air and $90 \% \pm 5 \%$ humidity for $24 \mathrm{~h}$. The culture medium was then removed and $250 \mu \mathrm{L}$ of NR solution were added to all wells. After incubation, the NR solution was removed and cells were rinsed with $250 \mu \mathrm{L}$ D-PBS. Subsequently $100 \mu \mathrm{L}$ NR Desorb (ETOH/acetic acid) solution was added to all wells for $20 \mathrm{~min}$ in order to extract NR from the cells and to form a homogeneous solution. The test was repeated in triplicate for each sample. The amount of dye accumulated into the cells was evaluated by means of spectrophotometry at $540 \mathrm{~nm}$ (Multiscan RC by Thermolab system, Finland). As already mentioned, DMEM without serum and phenol $0.45 \%$ were used as CTRL - and CTRL + references, respectively. The cells' morphology after $24 \mathrm{~h}$ direct contact with the samples was observed by means of an optical microscope (Nikon TMF, Japan).

The cell viability after exposure to the materials' extracts was further evaluated by means of XTT test, a colorimetric assay which is widely exploited in order to investigate both the mechanisms of cell damage and activation $[46,47]$. This protocol is based on the bioreduction of the (2,3-bis(2-methoxy-4-nitro-5-sulfophenyl)-5[(phenylamino) carbonyl]-2H-tetrazolium hydroxide) salt to form an orange formazan dye in metabolic active cells. BALB/3T3 cells were seeded in 96 well culture plates and subsequently incubated with samples' extracts for 24 h-48 h-72 h. Then XTT (Cell Proliferation Kit II (XTT) Roche Diagnostics, USA) was added (final concentration $0.3 \mathrm{mg} / \mathrm{ml}$ ). After $4 \mathrm{~h}$ incubation, the amount of the synthesized orange formazan dye generated from XTT, which directly correlates to the number of living cells, was measured by means of spectrophotometry at $490 \mathrm{~nm}$. DMEM without serum and phenol $0.45 \%$ were used as CTRL - and CTRL + references, respectively. 


\subsubsection{Statistical analyses}

One-way variance analysis (ANOVA) was employed to statistically treat the results, which are expressed as the mean \pm standard deviation. $t$-Test analysis by a two population comparison was used to establish differences among groups. Statistical significance was considered at a probability $p<0.05$.

\section{Results and discussion}

\subsection{Powder characterization and calcination effects}

Despite the different compositions of the glasses under investigation, the gelation time, which is the time required for the solution to become rigid, was similar for all the obtained gels. In particular BG_Ca, BG_Ca/Mix and BG_Ca/K gels were homogeneous, colorless and transparent. After milling and sieving, simultaneous TG and DTA were performed on as-dried gel powders to determine the best treatment to convert them into glass powders. The as-dried gel powders are expected to present significant weight losses because of the thermal decomposition of the precursors. The results of these tests are reported in Fig. 2. All the curves present a similar trend, which is characterized by:

- A first endothermic peak at about $140{ }^{\circ} \mathrm{C}$ in the DTA curves, which can be ascribed to the desorption of physically adsorbed water $[48,49]$;
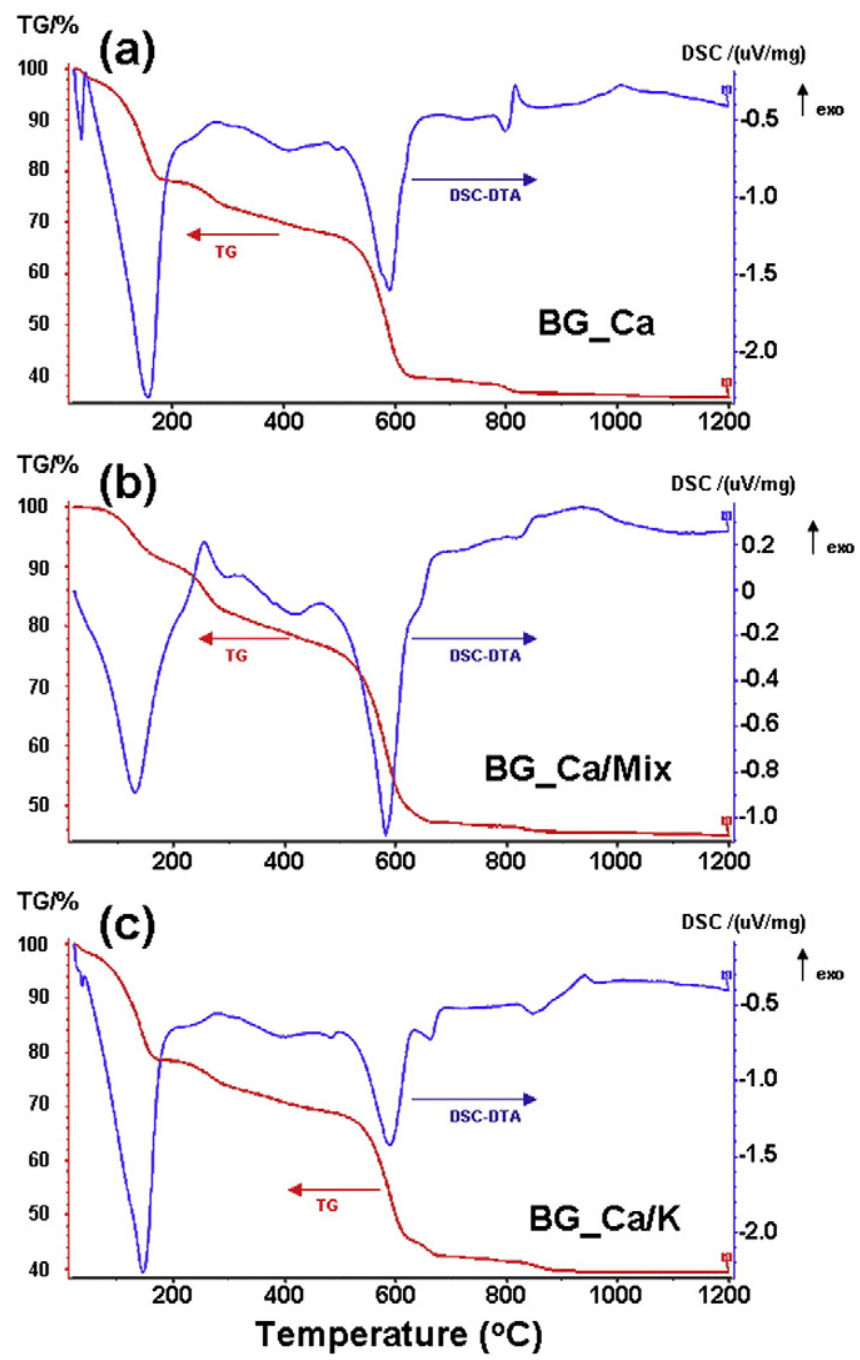

Fig. 2. TG and DTA curves of the as-dried gel powders. the TG curve shows a weight loss of about 20\% (BG_Ca and BG_Ca/K) and $10 \%$ (BG_Ca/Mix) up to $200{ }^{\circ} \mathrm{C}$ associated to this peak.

- An exothermic peak at about $250{ }^{\circ} \mathrm{C}$, which is more evident in the DTA curve of the BG_Ca/Mix. This peak can be ascribed to the volatilization of water, which is an exothermic chemical desorption process [21].

- Two endothermic peaks: the first one in the $410-420{ }^{\circ} \mathrm{C}$ range and the second one, which is particularly pronounced, in the $580-600{ }^{\circ} \mathrm{C}$ range. The TG curve shows the most critical mass loss between $500{ }^{\circ} \mathrm{C}$ and $650{ }^{\circ} \mathrm{C}$. The transformations occurring in this interval can be attributed to the decomposition of the organic precursors, to the removal of nitrate groups and, at the same time, to the condensation of the silanol groups $[14,20,48,50]$.

- The DTA curve of the BG_Ca gel (Fig. 2(a)) shows an endothermic peak at about $800{ }^{\circ} \mathrm{C}$ and, subsequently, an exothermic peak at about $830{ }^{\circ} \mathrm{C}$. The former is imputable to the glass transition and the latter to the crystallization of the glassy matrix [51,52]. The crystallization peak shifts to higher temperatures and gets particularly broad for the BG_Ca/Mix gel, while it can be observed at the highest temperature, i.e. $~ 930{ }^{\circ} \mathrm{C}$, for the BG_Ca/K gel, which confirms the very low tendency to crystallize of this formulation. It is interesting to note that, according to the DTA, the crystallization temperature of the BG_Ca/Kas-dried gel powders (i.e. $\sim 920{ }^{\circ} \mathrm{C}$ ) is the same as that previously detected for $\mathrm{M}$ powders of the same composition [34].

- Starting from $820^{\circ} \mathrm{C}$ all the TG curves reveal a substantial stability of the powders, except for the $\mathrm{BG}_{-} \mathrm{Ca} / \mathrm{K}$ which experiences a slight mass loss up to about $850{ }^{\circ} \mathrm{C}$.

XRD patterns of the gel powders calcined at different temperatures for $1 \mathrm{~h}$ are reported in Fig. 3. In agreement with the thermal analysis, BG_Ca/K remained substantially amorphous up to $900{ }^{\circ} \mathrm{C}$, while BG_Ca remained amorphous up to $800{ }^{\circ} \mathrm{C}$ and BG_Ca/Mix up to $700{ }^{\circ} \mathrm{C}$. To the authors' best knowledge, no other SG bioactive glasses in the
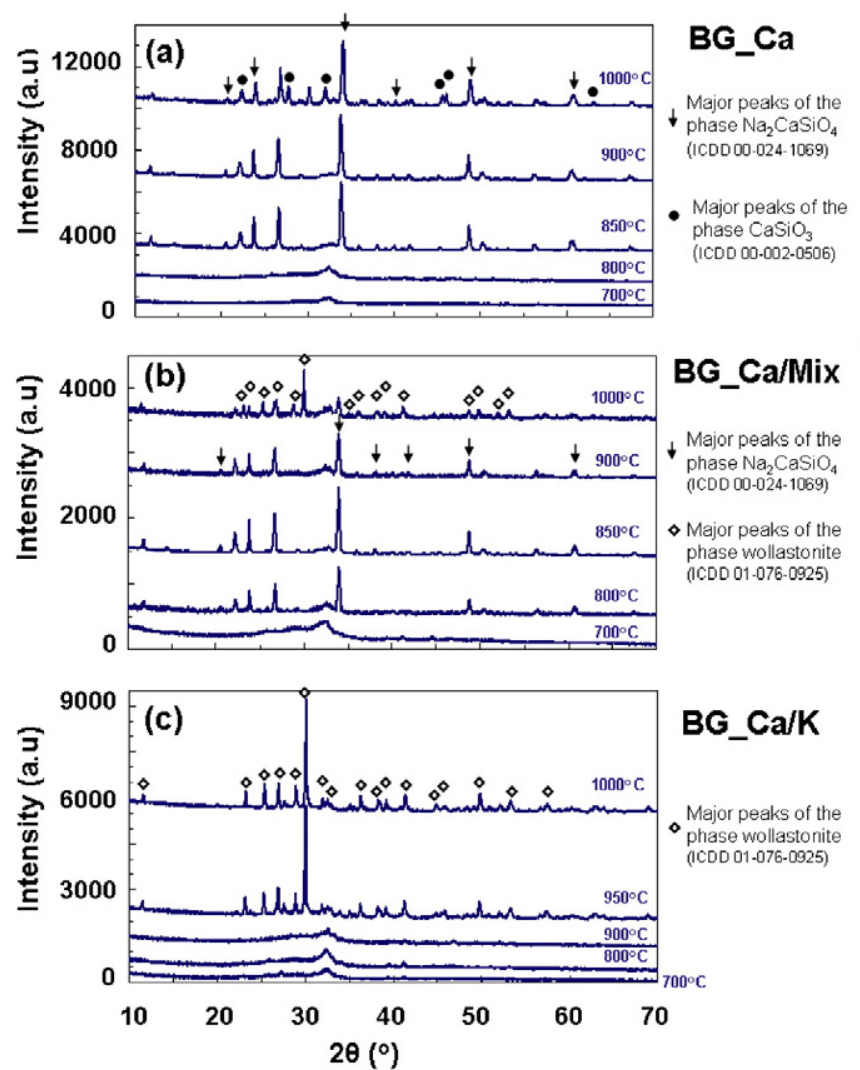

Fig. 3. XRD patterns of the gel powders treated at different temperatures for $1 \mathrm{~h}$. 
literature show such a high crystallization temperature; in particular, the BG_Ca/K can be surely included among the SG bioactive systems with the highest crystallization temperature. Therefore, like the M counterparts, also the SG glasses benefit from the high $\mathrm{CaO}$ content and from the partial (or complete for BG_Ca/K) substitution of sodium oxide with potassium oxide in their formulation [33,34]. During the calcination, the crystallization of the SG BG_Ca samples results in a sodium calcium silicate, $\mathrm{Na}_{2} \mathrm{CaSiO}_{4}$ (ICDD 00-024-1069), and a calcium silicate, $\mathrm{CaSiO}_{3}$ (ICDD 00-002-0506) (Fig. 3a). The SG BG_Ca/Mix samples crystallize with the development of the same sodium calcium silicate, $\mathrm{Na}_{2} \mathrm{CaSiO}_{4}$ (ICDD 00-024-1069), and of wollastonite (ICDD 01-076-0925) (Fig. 3b). The crystallization of the BG_Ca/K samples starts at about $900{ }^{\circ} \mathrm{C}$, but the peaks are still very weak and their attribution to wollastonite (ICDD 01-0760925) becomes unambiguous only at $950{ }^{\circ} \mathrm{C}$ (Fig. 3c). The M counterparts substantially show the formation of the same crystalline phases, i.e. wollastonite and sodium-calcium silicates [33,34], whose in vitro bioactivity has been widely documented in literature [53-56].

Fig. 4 compares the SEM micrographs of the SG powders to those of the heat-treated-M counterparts after thermal treatment at $850{ }^{\circ} \mathrm{C}$ for $1 \mathrm{~h}$. The spectra of the EDS analyses are also reported and it should be

(a)

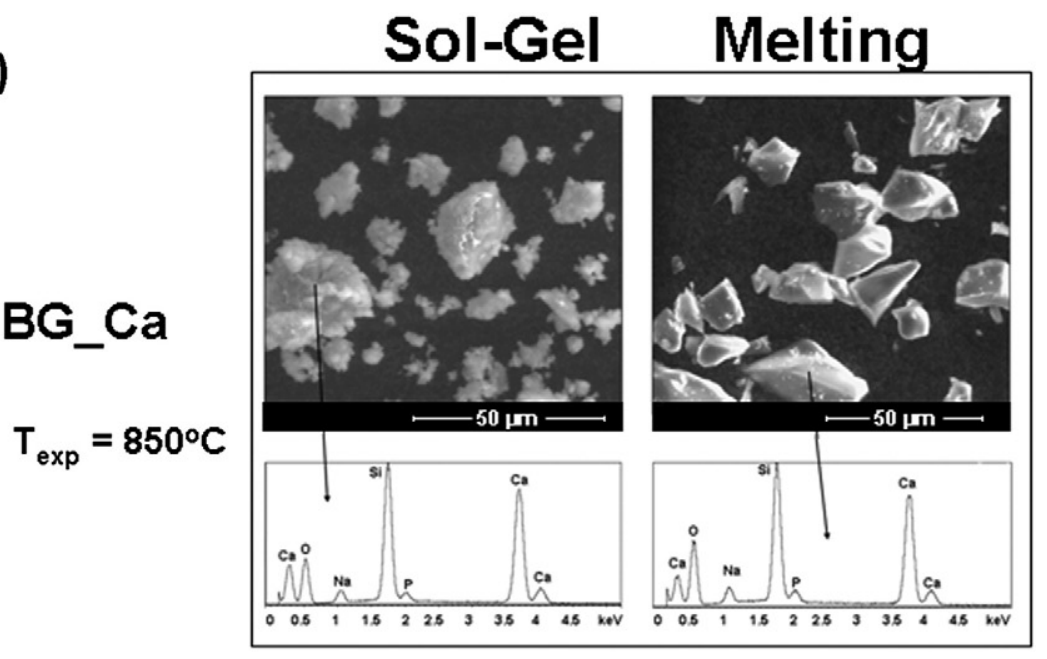

(b)

BG_Ca/Mix

$\mathrm{T}_{\text {exp }}=850^{\circ} \mathrm{C}$
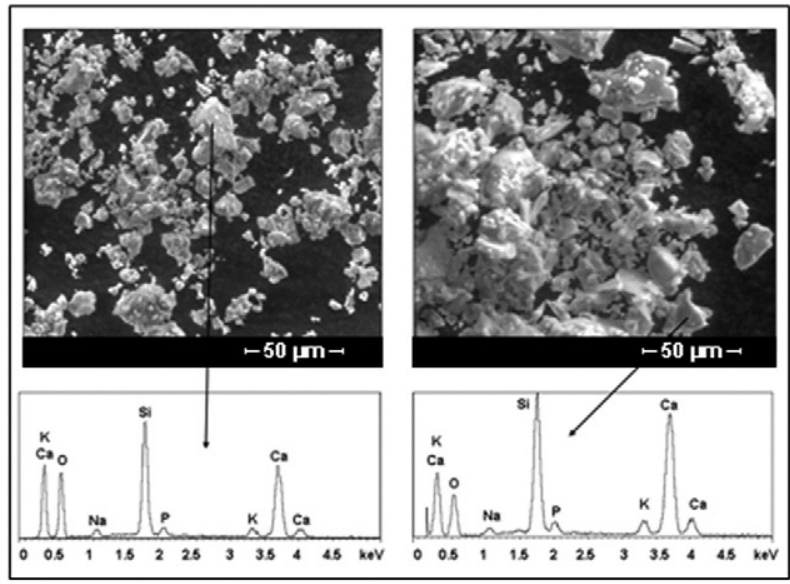

(c)

BG_Ca/K

$T_{\exp }=850^{\circ} \mathrm{C}$
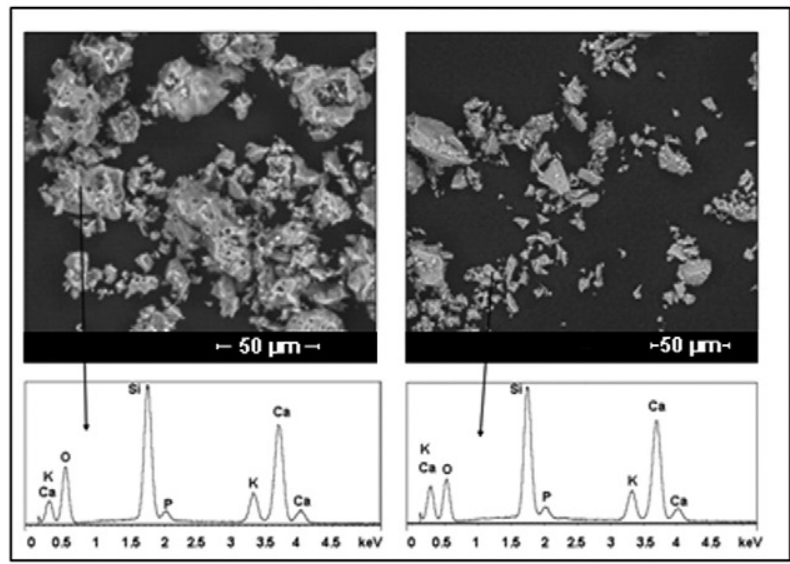

Fig. 4. SEM micrographs of the SG powders and heat-treated-M counterparts calcined at $850{ }^{\circ} \mathrm{C}$ for $1 \mathrm{~h}$. 
noted that it was not possible to detect the presence of chemical species imputable to residues of precursors in the SG powders.

On the basis of TG-DTA, XRD and EDS analyses, the SG powders calcined at $850{ }^{\circ} \mathrm{C}$ for $1 \mathrm{~h}$ were chosen for further investigation and therefore the following discussion will be dedicated to such calcined powders only. For this reason, in the following discussion, the label "SG" will be used to indicate the sol-gel samples treated at $850{ }^{\circ} \mathrm{C}$ for $1 \mathrm{~h}$ without any further specifications. This temperature, $850{ }^{\circ} \mathrm{C}$, was selected as a compromise between the need to decompose the precursors completely (according to the DTA, the BG_Ca/K presents a slight mass loss up to about $850{ }^{\circ} \mathrm{C}$ ) and the possibility to minimize the devitrification (according to the XRD, the BG_Ca/Mix starts its crystallization at $700{ }^{\circ} \mathrm{C}$, but $850{ }^{\circ} \mathrm{C}$ is comparable to the crystallization temperature of the BG_Ca glass and it is definitely lower than that of $\mathrm{BG}_{-} \mathrm{Ca} / \mathrm{K}$, which remains substantially amorphous up to $900{ }^{\circ} \mathrm{C}$ ). For comparison, the XRD spectra obtained on heattreated-M powders after heat treatment at $850{ }^{\circ} \mathrm{C}$ for $1 \mathrm{~h}$ are reported in Fig. 5. In agreement with previous results regarding the same compositions [33,34], heat-treated-M BG_Ca undergoes crystallization with the formation of $\mathrm{Na}_{2} \mathrm{CaSiO}_{4}$, while heat-treated-M BG_Ca/ Mix and heat-treated-M BG_Ca/K remain substantially amorphous. So it is interesting to note that, if melt-derived glasses are considered, the BG_Ca composition has the lowest crystallization temperature (it is partially crystallized after $1 \mathrm{~h}$ at $850{ }^{\circ} \mathrm{C}$, whereas both the BG_Ca/K and BG_Ca/Mix compositions are still amorphous after the same heat treatment); if sol-gel glasses are considered instead, the SG BG_Ca/Mix glass is the first one to devitrify, since it starts to crystallize after $1 \mathrm{~h}$ at $800{ }^{\circ} \mathrm{C}$ (see Fig. 3(b)).

\subsection{Sintering behavior and microstructure characterization of fully dense bodies}

The sintering temperature of the SG calcined powders was determined by an optical thermo-dilatometric analysis. The curve of SG BG_Ca/K powder is shown in Fig. 6. The curves obtained for SG BG_Ca and SG BG_Ca/Mix are omitted for the sake of brevity, since they are very similar to the BG_Ca/K one. A significant contraction can be observed in the $760{ }^{\circ} \mathrm{C}-830{ }^{\circ} \mathrm{C}$ range and the best sintering temperature, which corresponds to the maximum shrinkage rate, can be fixed at $\mathrm{T}_{\text {sint }}=800^{\circ} \mathrm{C}$. If the temperature increases, the sample starts to expand. Unfortunately, the test suddenly interrupts at about $850{ }^{\circ} \mathrm{C}$ due to an experimental limit, since the sample expands so fast that the instrument is not able to track it. Similar expansion phenomena have been reported in the literature also for sol-gel 45S5 Bioglass ${ }^{\circledR}[20]$. According to the results of the thermo-dilatometric analysis, therefore, SG green bodies were treated at $\mathrm{T}_{\text {sint }}=800{ }^{\circ} \mathrm{C}$ for $3 \mathrm{~h}$. Indeed, it cannot be excluded that a second sintering step might occur at a higher temperature, as reported in the literature for M glasses of the same BG_Ca family [33,34] and for SG 45S5 Bioglass $®$ [20]. However, a treatment at $800{ }^{\circ} \mathrm{C}$ is expected to promote a strong densification (see dilatometric curve, Fig. 6) and, at the same time, to limit the crystallization.

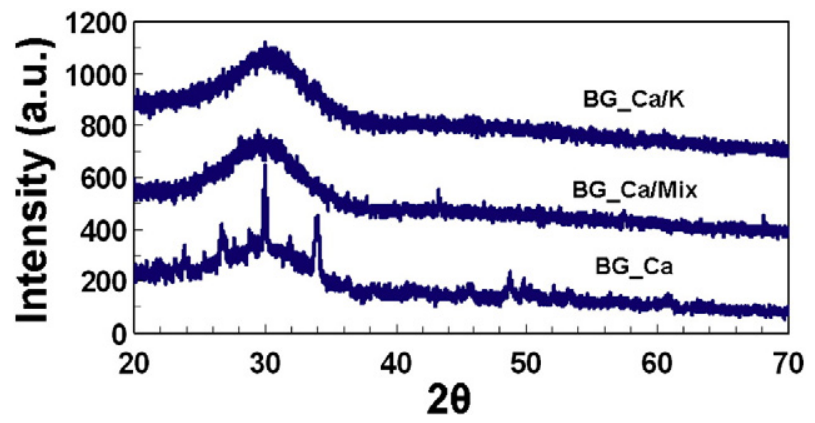

Fig. 5. XRD patterns of the heat-treated-M powders after thermal treating at $850{ }^{\circ} \mathrm{C}$ for $1 \mathrm{~h}$.

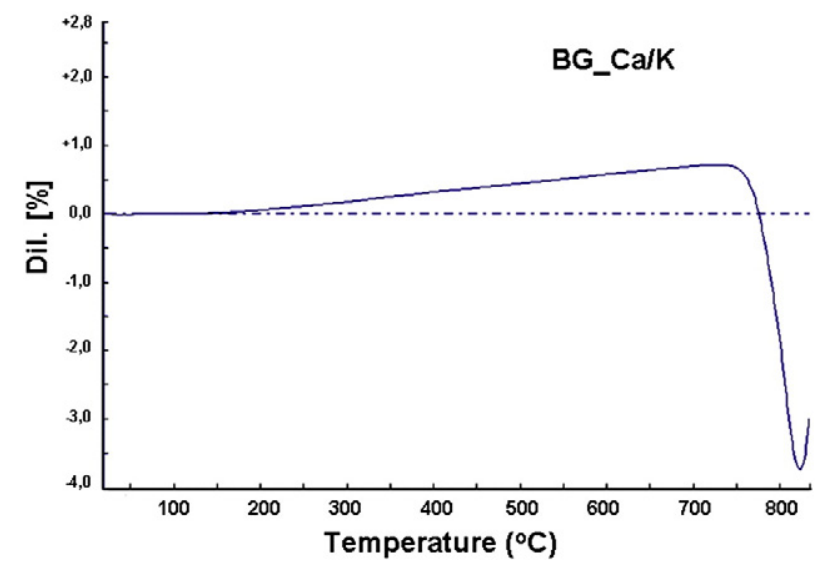

Fig. 6. Thermo-dilatometric curve of the calcined SG BC_Ca/K powders.

The cross-sections of the SG samples sintered at $800{ }^{\circ} \mathrm{C}$ for $3 \mathrm{~h}$ are shown in Fig. 7. The SEM images confirm that all the samples are compact and well consolidated. The corresponding values of density and volume shrinkage, expressed as mean value \pm standard deviation, are reported in Table 1. For comparison, $\mathrm{M}$ green bodies were produced and heat treated with the same thermal cycle. The density and the volume shrinkage of the $\mathrm{M}$ samples sintered at $\mathrm{T}_{\text {sint }}$ are also reported in Table 1. It is possible to note that the volume shrinkage of the M samples is remarkably stronger with respect to the SG counterparts, in particular for the BG_Ca/Mix glass. It cannot be excluded that a slight development of gaseous by-products might occur during sintering, as lately proposed for SG 45S5 Bioglass ${ }^{\circledR}[20]$. It should be stressed that, as a rule, relevant volume shrinkages may be detrimental to produce highly porous scaffolds for bone regeneration and repair, since strong dimensional changes during the sintering process may result in the formation of a poorly interconnected porosity with clogged pores. In fact, the M glasses belonging to the BG_Ca family, which experience a remarkable volume change, are not suitable for the production of pure glass scaffolds. On the contrary, the SG counterparts seem to be ideal candidates to manufacture highly porous devices, as reported in the next paragraphs.

The XRD spectra acquired on the SG samples sintered at $800{ }^{\circ} \mathrm{C}$ for $3 \mathrm{~h}$ are presented in Fig. 8. The XRD test was repeated on the sintered samples, because the very long treatment $(3 \mathrm{~h})$ at $800{ }^{\circ} \mathrm{C}$ could favor the development of (new) crystalline phases. However, it is interesting to note that it was possible to preserve the amorphous nature of SG BG_Ca/K glass, which was still amorphous at the end of the sintering process. This result further confirms the extraordinary low tendency to crystallize of the SG BG_Ca/K glass. Instead the BG_Ca and BG_Ca/Mix sintered samples were partially crystallized, but this is not surprising, since the powders were already partially crystallized after the calcination step (Fig. 3).

\subsection{SG BG_Ca/K shell scaffolds}

In previous contributions [37,38], shell scaffolds were produced by means of a new protocol inspired by the traditional foam replication technique [29]. The main objective was to obtain highly porous samples which could be easy to handle thanks to their external surface, acting as a resistant but at the same time permeable shell, i.e. a sort of exoskeleton which supports the inner sponge-like network [37]. However, in order to produce such samples, conventional melt-derived glass powders were used and relatively high temperature treatments $\left(\sim 1050{ }^{\circ} \mathrm{C}\right.$ for $3 \mathrm{~h}$ ) were necessary to consolidate the scaffolds, which therefore resulted to be crystallized $[37,38]$.

In the present contribution, since the thermal behavior of the SG BG_Ca/K powders was extremely promising, an attempt was made to 
BG_Ca

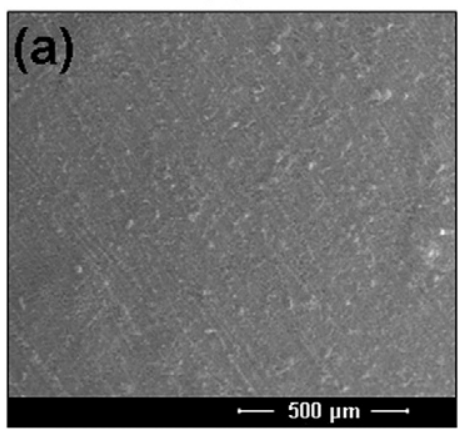

BG_Ca/Mix

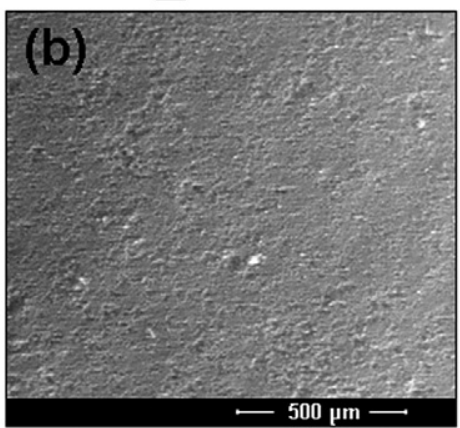

BG_Ca/K

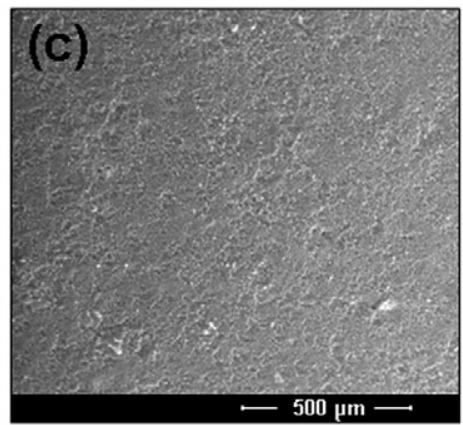

Fig. 7. Cross-sections of the SG samples sintered at $800{ }^{\circ} \mathrm{C}$ for $3 \mathrm{~h}$.

produce SG BG_Ca/K shell scaffolds, aiming to obtain not crystallized samples due to the unique properties of sol-gel derived glass powders.

The SG BG_Ca/K shell scaffolds looked extremely porous, but still easy to handle, due to the strong outer "shell". The permeability of the scaffolds' surface (i.e. the "shell") was qualitatively confirmed by means of capillarity tests performed according to the protocol reported in Refs. [40,41]. In Fig. 9 it is possible to observe a sample during (Fig. 9(a, b)) and immediately after (Fig. 9(c)) the test. In about 3 $s$ the whole scaffold became blue as a result of the fluid infiltration through its pore network. After the fluid adsorption, each sample was cut in two pieces to observe its cross-section. The scaffolds were uniformly impregnated and, in particular, the presence of the blue solution in their interior further confirms the permeability of the samples' surface and their open and fully interconnected porous structure.

The total porosity of the samples, as calculated from density measurement and further confirmed by image analysis, was about 80 vol.\%. SEM micrographs of the internal structure of the SG BG_Ca/K shell scaffolds are reported in Fig. 10. It should be noted that the complex network of struts and macropores reproduces the shape of the spongy template [39]. The pores of the scaffolds are mostly open and interconnected, a result which had never been reached in the past with $\mathrm{M}$ glass powders of the BG_Ca family. As shown in Fig. 10, the SG BG_Ca/K shell scaffolds are characterized by a macroporosity whose size is between $200 \mu \mathrm{m}$ and $500 \mu \mathrm{m}$, a value which satisfies the requirements to allow cell infiltration and new vascularization [57]. Moreover the scaffolds present a widespread microporosity, which is able to promote the diffusion of fluids, and by a rough surface of the struts, which is expected to help cell adhesion after implantation [58]. In fact, as shown in the high-magnification image, Fig. 10(d), the morphology of the original particles is still perceivable on the surface of the splats. Unfortunately, a direct measurement of the roughness of the struts is not feasible, due to the complex shape of the scaffolds and the very fine dimension of the original particles. Finally, it should be stressed that the obtained

Table 1

Density (mean value \pm standard deviation) and volume shrinkage (mean value \pm standard deviation) of the SG samples and of the M counterparts sintered at $\mathrm{T}_{\operatorname{sint}}=800^{\circ}$ $\mathrm{C}$ for $3 \mathrm{~h}$.

\begin{tabular}{llcc}
\hline Sample code & Manufacturing process & Density $\left(\mathrm{g} / \mathrm{cm}^{3}\right)$ & Volume shrinkage (\%) \\
\hline BG_Ca & Sol-gel & $1.43 \pm 0.15$ & $13.88 \pm 0.65$ \\
& Melting & $2.47 \pm 0.12$ & $17.08 \pm 1.13$ \\
BG_Ca/Mix & Sol-gel & $1.33 \pm 0.14$ & $2.17 \pm 0.08$ \\
& Melting & $2.53 \pm 0.15$ & $17.62 \pm 0.58$ \\
BG_Ca/K & Sol-gel & $1.29 \pm 0.12$ & $9.42 \pm 0.17$ \\
& Melting & $2.53 \pm 0.28$ & $16.93 \pm 0.99$ \\
\hline
\end{tabular}

samples are almost amorphous (data not shown) and therefore they are expected to be highly bioactive.

In spite of their rich porosity, the scaffolds proved to have good mechanical properties. In fact, during the compression tests, the stress increases moderately in a first stage, and very quickly in a second stage, with a maximum yield strength of about $0.6-0.7 \mathrm{MPa}$; after that, the stress drops, due to the progressive break down of the structure. The same behavior has been observed in the past for shell scaffolds produced with melt-derived glass powders [37]. The mechanical behavior is therefore mainly governed by the structure of the scaffolds, especially by the presence of the external shell, whereas the technique to produce the powders, sol-gel instead of melting, plays a marginal role. It is worth noting that the achieved yield strength is comparable to or even higher than the compressive strength commonly reported in the literature for glass-based scaffolds, produced by standard replication method, from melt-derived powders and with analogous total porosity $[29,37,59,60]$. On the contrary, a comparison with the mechanical strength of spongy bone is not straightforward, since bone has anisotropic mechanical properties characterized by heterogeneity with respect to anatomic site, age, health and disease-related variations in trabecular architecture, loading mode and direction. However, the yield strength of the sol-gel derived scaffolds is compatible with the compression resistance of spongy bone, which is in the 0.3-8 MPa range [61], although it lies closer to the lower bound. Other authors in the literature report an even wider range for the mechanical strength of spongy bone, i.e. 0.1-30 MPa [62].

\subsection{Assessment of the in vitro bioactivity}

The apatite-forming ability of the produced SG-samples (dense sintered bodies and scaffolds) was tested in vitro through the immersion in a Simulated Body Fluid (SBF) solution for a given period of

$\downarrow$ Major peaks of the phase $\mathrm{Na}_{2} \mathrm{CaSiO}_{4}$ ICDD (01-073-1726)

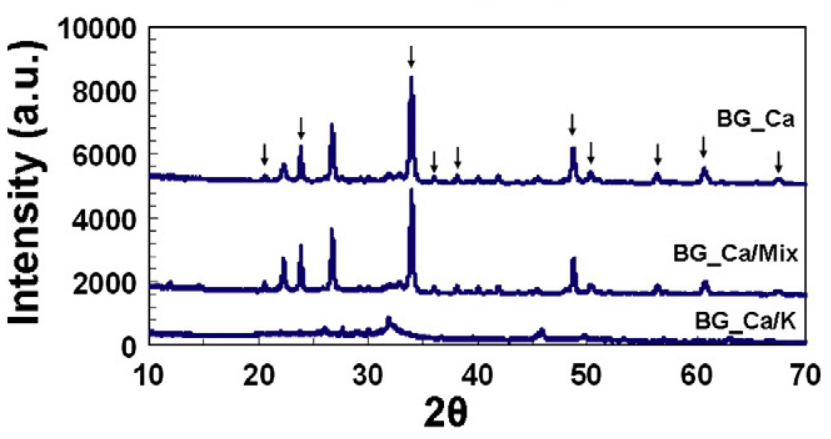

Fig. 8. XRD patterns of the SG samples sintered at $800{ }^{\circ} \mathrm{C}$ for $3 \mathrm{~h}$. 

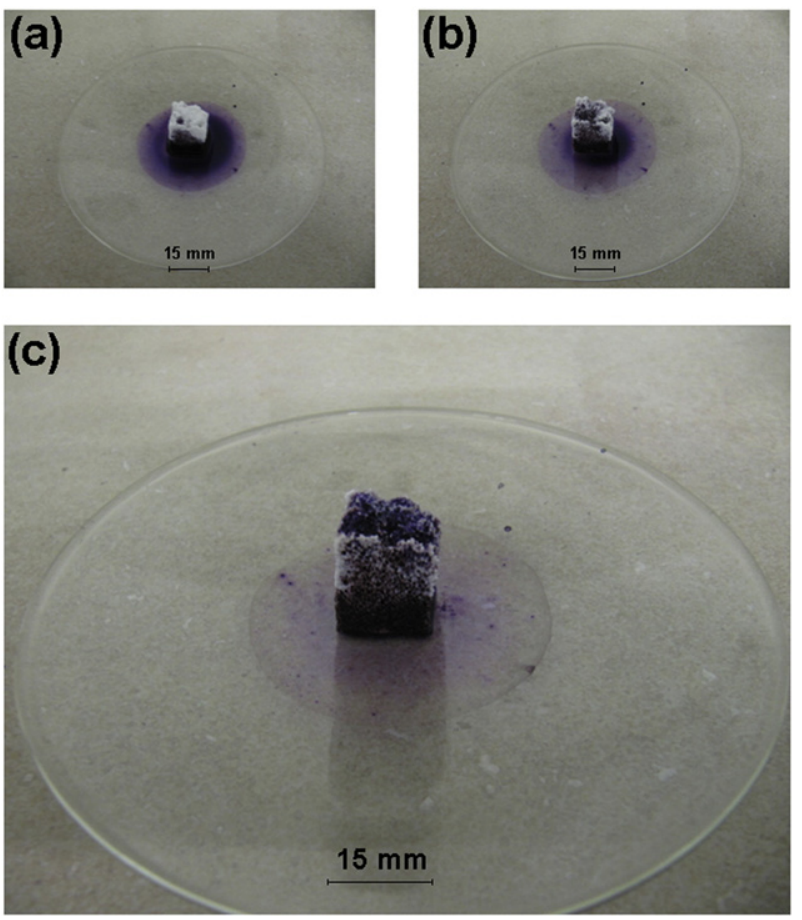

Fig. 9. Capillarity test performed on a shell scaffold.

time, according to the procedure proposed by Kokubo [36,42]. In the last few years several authors have questioned the predictive ability of these assays, which cannot mimic the real physiological conditions and may lead to misunderstand the behavior of a given material once embedded in a biological context [63-65]. Moreover, it should be stressed that a favorable environment in terms of ionic concentration is just one of the many conditions necessary for bone regeneration, which is a complex, well-orchestrated physiological process. On the other hand, even if the apatite-forming ability is not immediately equivalent to the bonebonding ability, SBF trials are relatively easy and cheap and therefore they are widely used by the scientific community. They should be considered as an introductory inquiry into the bio-reactivity of a given non-toxic material.

Fig. 11 shows the surface of sintered (not porous) SG glass samples (SG BG_Ca, SG BG_Ca/Mix and SG BG_Ca/K fully dense bodies, fired at $800{ }^{\circ} \mathrm{C}$ for $3 \mathrm{~h}$ ) soaked in SBF for increasing times. After 3 days, all the samples have already started their interaction with the SBF solution and their surface is covered by spherical aggregates with the typical apatite morphology. The amount of the deposited apatite increased with increasing soaking time, as also confirmed by the cross sectional images (data not shown for the sake of brevity). In particular, after 14 days in SBF all samples are covered by an apatite film which has a thickness of some micrometers (about 2-3 $\mu \mathrm{m}$ ). The results show that the SG BG_Ca/K sample possessed the strongest apatite-forming ability. This is probably due to the presence of potassium, which is higher in the BG_Ca/K formulation than in the other two. As a matter of fact, as reported by Vitale-Brovarone et al. [66] in a contribution concerning a bioactive glass belonging to the $\mathrm{K}_{2} \mathrm{O}-\mathrm{CaO}-\mathrm{SiO}_{2}$ system, the high bioactivity observed for their glass could be partly ascribed to the presence of $\mathrm{K}^{+}$in the glass formulation. According to the Hench's model [2], in fact, the first chemical step of the bioactivity mechanism, which leads to the apatite precipitation on the glass surface, involves an exchange of alkali (or alkaline-earth) cations from the glass with $\mathrm{H}^{+}$or $\mathrm{H}_{3} \mathrm{O}^{+}$ions from the physiological solution. However, $\mathrm{Na}^{+}$has a relatively small radius (0.95 $\AA$ ) if compared with $\mathrm{K}^{+}\left(1.33 \AA\right.$ ), therefore the $\mathrm{K}^{+} / \mathrm{H}^{+}$exchange
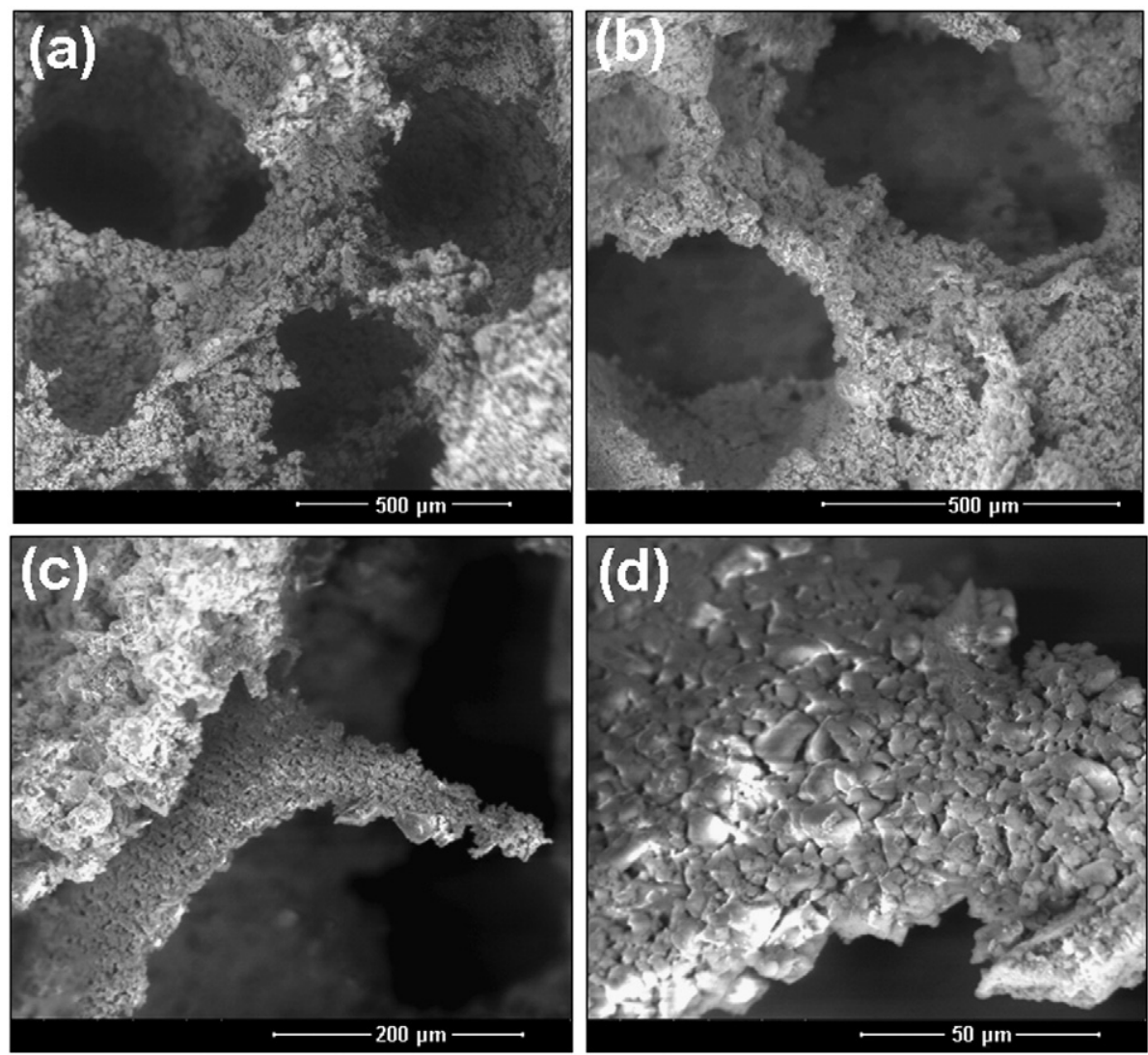

Fig. 10. SEM micrographs showing the internal structure of the SG BG_Ca/K shell scaffold (sample fired at $\mathrm{T}=800{ }^{\circ} \mathrm{C}$ for $3 \mathrm{~h}$ ). 


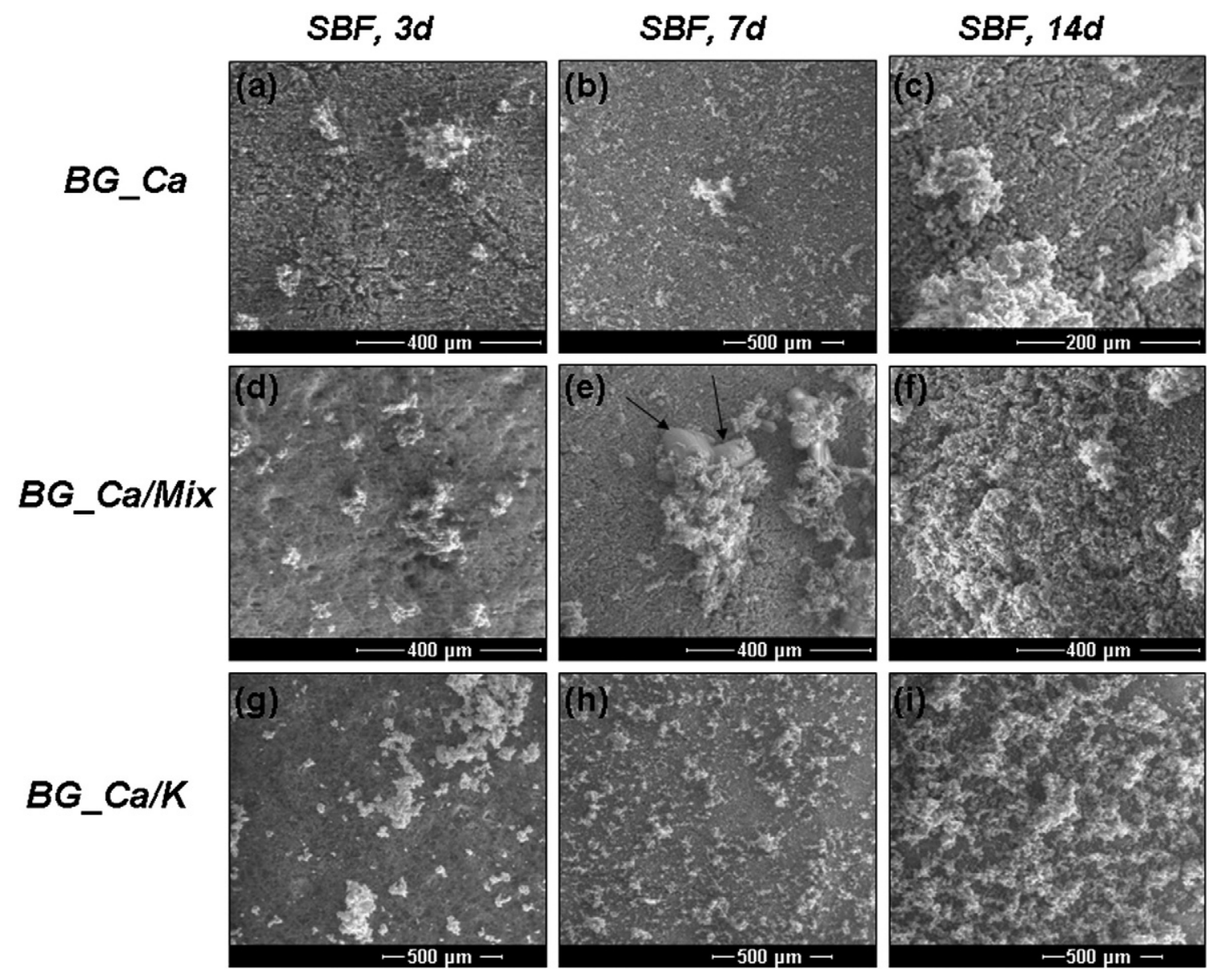

Fig. 11. Surface of the sintered (not porous) SG glass samples soaked in SBF for increasing times.

phenomena have a more "disruptive" effect on the glass matrix than $\mathrm{Na}^{+} / \mathrm{H}^{+}$ones, so the release of $\mathrm{K}^{+}$ions is more effective to increase the glass specific surface area available for further reactions.

The identification of the observed globular precipitates as apatite was confirmed by EDS analysis, XRD and micro-Raman investigation. Already after 3 days in SBF, apart from local fluctuations, the EDS results revealed the presence of $\mathrm{P}$ and $\mathrm{Ca}$, with a Ca-to-P ratio of about 1.8 , which is comparable to the typical value of stoichiometric apatite, i.e.
1.67 [67]. As an example, the EDS spectra acquired on SG BG_Ca/K samples are reported in Fig. 12. The presence of a weak Si signal in the spectrum (Fig. 12(b)) is imputable to the silica gel underneath the apatite precipitates [2], while the presence of $\mathrm{Cl}$ is ascribable to chloride compounds precipitated from the solution, as often documented in literature $[68,69]$. The formation of an apatite layer during the immersion in SBF was also evidenced by the XRD analyses. The diffraction patterns of the SG BG_Ca/K samples before and after soaking in SBF for different

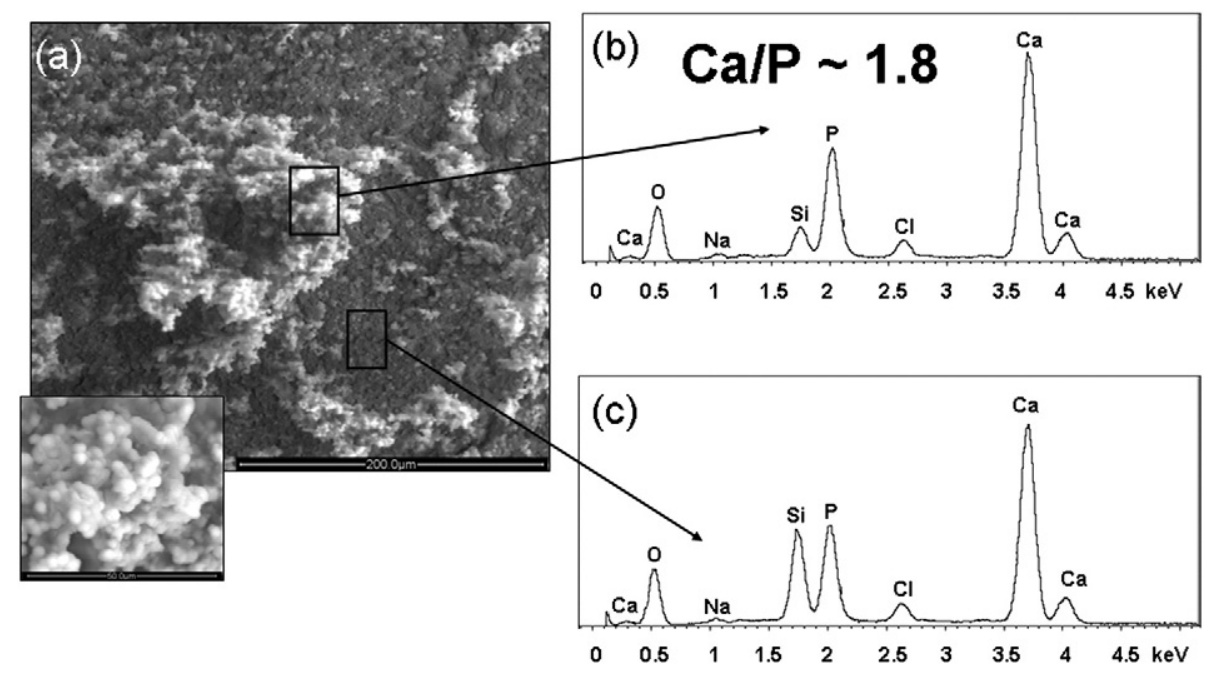

Fig. 12. Surface of sintered SG BG_Ca/K samples after soaking in SBF for 3 days (a) and EDS spectra (b, c) acquired on the areas reported in (a). 


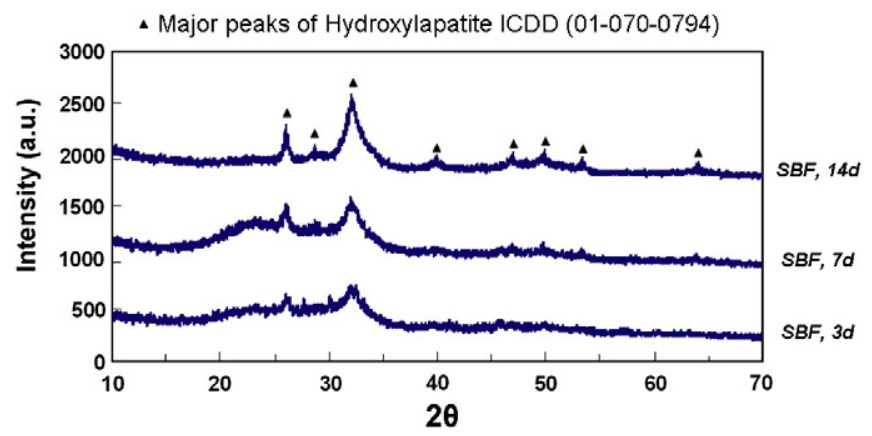

Fig. 13. XRD spectra of the sintered SG BG_Ca/K samples soaked in SBF for increasing times.

periods of time are shown in Fig. 13; since the trends for the XRD patterns obtained on the SG BG_Ca and SG BG_Ca/Mix samples are similar to the SG BG_Ca/K ones, they were not reported. Before the immersion in SBF, as discussed in previous paragraphs, the XRD spectrum confirms the amorphous nature of the sample, since it is characterized by a broad halo between $30^{\circ}$ and $35^{\circ}(2 \theta)$; the broad peak at about $46^{\circ}(2 \theta)$ is due to the sample holder (see Fig. 8). With increasing times in SBF, a new halo became visible at lower diffraction angles $\left(20^{\circ}-35^{\circ} 2 \theta\right.$ range); this "bump", which can be connected to the silica gel layer [70] already detected by the X-EDS analysis, is particularly evident after 7 days in SBF. The signal at $2 \theta \sim 32^{\circ}$, which became sharper and more intense for longer soaking times, corresponds to the (211) reflection of apatite. Its broad shape, which is particularly evident for short soaking times, is due to the microcrystalline nature of the apatite precipitates [71]. The peak at $2 \theta \sim 26^{\circ}$ also becomes very sharp and it is imputable to the $(0$ 02 ) apatite diffraction peak, while the secondary peaks at $2 \theta \sim 39^{\circ}$ and $\sim 46^{\circ}$ correspond to the ( $\left.\begin{array}{lll}3 & 1 & 0\end{array}\right)$ and $\left(\begin{array}{lll}2 & 1 & 3\end{array}\right)$ apatite diffraction peaks, respectively $[72,73]$. The obtained spectra contained peaks corresponding to those of a reference apatite (ICDD 01-070-0794).

The chemistry of the precipitated apatite was further investigated by means of micro-Raman spectroscopy. Fig. 14 reports some illustrative spectra acquired on the globular crystals which cover the SG glass samples after 7 days in SBF. All spectra display the characteristic peaks of apatite: a peak at $\sim 950 \mathrm{~cm}^{-1}$ and two peaks at about $430 \mathrm{~cm}^{-1}$ and $590 \mathrm{~cm}^{-1}$, which are imputable to the stretching of the $\left(\mathrm{PO}_{4}\right)^{3-}$ groups [74,75]. In addition, a peak at $\sim 1070 \mathrm{~cm}^{-1}$, which can be referred to the stretching of a carbonate group, can be observed. Therefore, it is possible to conclude that the formed apatite is carbonated [76].

The bioactivity of SG BG_Ca/K shell scaffolds (samples treated at $\mathrm{T}_{\text {sint }}=800{ }^{\circ} \mathrm{C}$ for $3 \mathrm{~h}$ ) was investigated in the same way. The scaffolds' internal structure after immersion in SBF for 7 days is shown in Fig. 15, which also includes an EDS spectrum acquired on the precipitates which cover the surface of the struts. It is evident that the apatite agglomerates uniformly covered the internal pore walls and the trabeculae between them. The EDS analysis revealed the presence of $\mathrm{P}$ and $\mathrm{Ca}$ in a proportion of about 1.75 (with fluctuations

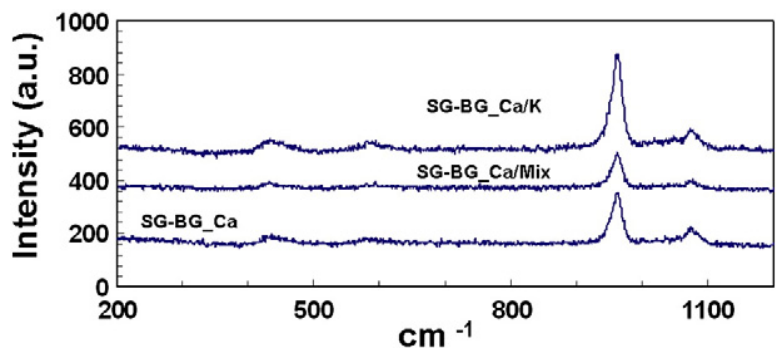

Fig. 14. Raman spectra acquired on the globular precipitates which cover the sintered SG glass samples after soaking in SBF for 7 days. caused by the local nature of the technique), which supports the identification of the precipitates as hydroxyapatite.

All the samples showed a good trend of $\mathrm{pH}$ neutralization during in vitro tests. In fact, the $\mathrm{pH}$ of the SBF (which was refreshed three times a week) did not exceed 8.3 and, after 14 days, almost stabilized to physiological values (7.4-7.5).

\subsection{Cytotoxicity tests}

Testing the effects of new compounds and their degradation products on the viability of cells grown in culture is a commonly used tool to go beyond the findings from SBF assays. The main objective is to predict potential toxic effects in whole animals of materials intended for biomedical applications. To this aim, the cytotoxicity of the SG sintered samples was tested using BALB/3T3 mouse fibroblast cells, a very common immortalized cell line which conforms with the International Standards Organization (ISO) requirements for investigating the cytotoxicity of biomaterials $[43,44]$. The morphology of the cells after $24 \mathrm{~h}$ direct contact with the samples was observed by means of an optical microscope, as shown in Fig. 16. No significant morphological changes such as cell shrinkage, rounding, lysis etc. can be observed with respect to the CTRL - . In particular, even if the composition of the samples differs, no relevant effects can be noted on the cells' behavior. The results of the viability test performed with NR uptake confirm these considerations (see Fig. 17(a)). NR assays, which provide a quantitative evaluation of the number of viable, damaged and dead cells in a culture, rely on the ability of viable cells to absorb and concentrate the supravital dye neutral red in lysosomes [45]. The chemical exposure to toxic xenobiotics is expected to alter this process, thus resulting in a decreased NR uptake and binding. Cell cultures are usually examined after one cell cycle, i.e. 24 h. The results shown in Fig. 17(a) do not report significant reduction in the lysosomal activity of BALB/3T3 cells in contact with SG BG_Ca/K, BG_Ca/Mix and BG_Ca. In particular, NR uptake is similar to CTRL - for all samples. Cell viability was further evaluated by means of XTT reduction assay, which measures metabolically active viable cells through their ability to convert tetrazolium salts, such as XTT, MTT, MTS, and WST, into intensely colored formazan dyes, which can be easily measured by spectrophotometry [47,77-79]. The colored product is proportional to the number of viable cells. XTT has become increasingly popular among metabolic dyes mainly because it is reduced by cells into a water-soluble formazan dye, thus eliminating the solubilization step required for the MTT assay, which has been the main hurdle with viability methods for many years. The XTT results reported in Fig. 17(b) show that SG sintered glasses do not affect negatively the vitality of the cells. Based on this preliminary biological evaluation, it is possible to hope for an in vivo biocompatibility of the synthesized glasses.

\section{Conclusions}

In the present contribution a new protocol to produce quaternary bioactive glasses by means of the sol-gel (SG) method was presented and discussed. Due to the special composition of the glasses, which are characterized by a high content of $\mathrm{CaO}(45.6 \mathrm{~mol} \%)$ and a low amount of alkaline oxides, $\mathrm{Na}_{2} \mathrm{O}$ and/or $\mathrm{K}_{2} \mathrm{O}$ (tot. $4.6 \mathrm{~mol} \%$ ), the temperature required to decompose the chemical precursors is lower or comparable to the crystallization temperature (in the $700-900{ }^{\circ} \mathrm{C}$ range, depending on the specific glass composition) so, for the first time, it was possible to produce four-oxide bioactive glasses by the sol-gel method and to sinter them $\left(\mathrm{T}_{\text {sint }}=800{ }^{\circ} \mathrm{C}\right)$ preserving their amorphous character, with a technological protocol which is cheaper than those usually reported in the literature. In particular, the composition with the highest potassium content (BG_Ca/K) did not undergo any sensible crystallization phenomena. The bioactivity of the obtained samples was tested in vitro in SBF with excellent results 

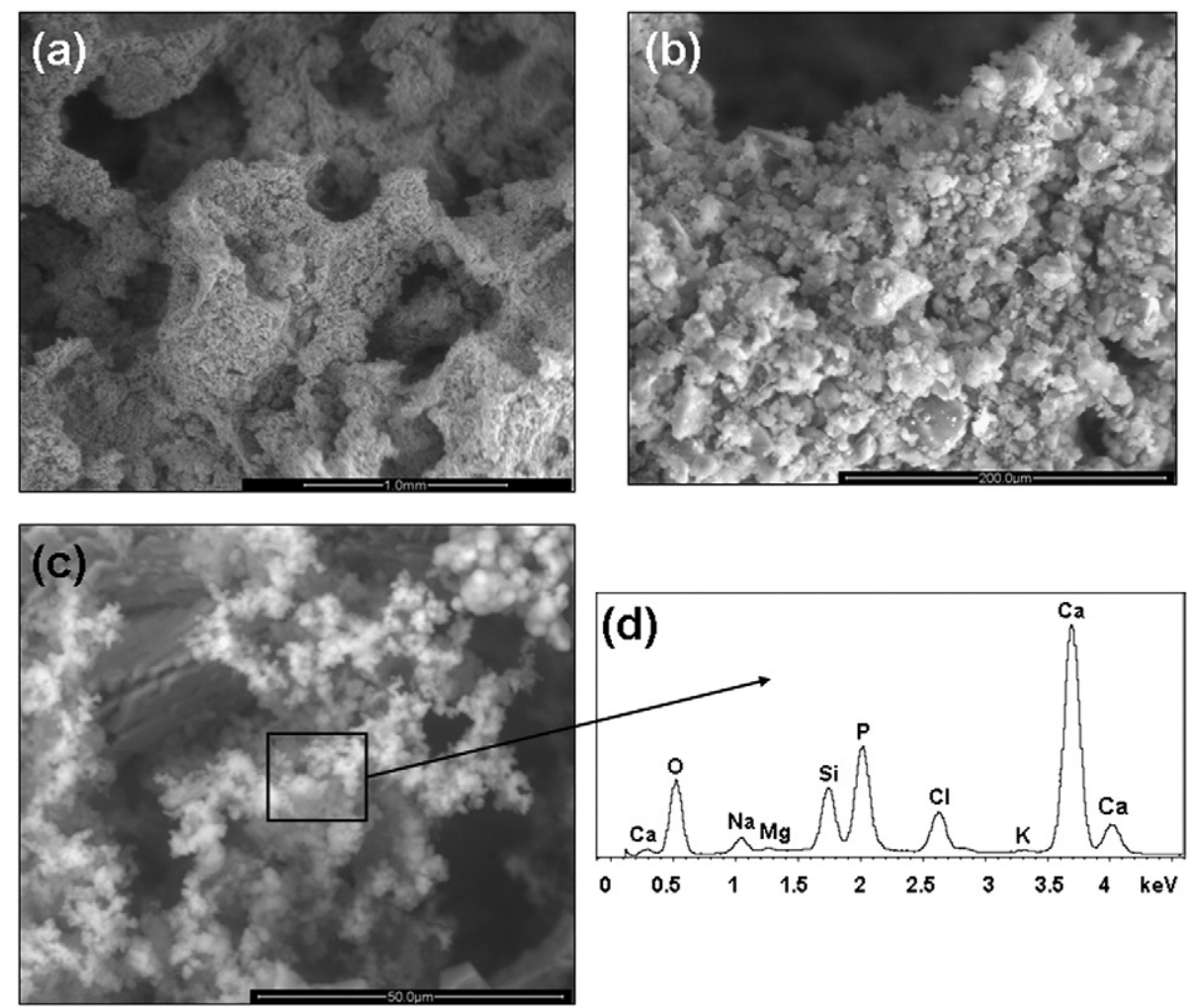

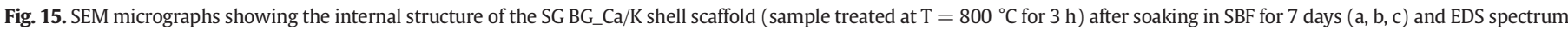
(d) acquired on the area reported in (c).

both in terms of apatite forming ability and of $\mathrm{pH}$ variation induced in the solution. Moreover, cytotoxicity tests performed with murine fibroblasts (BALB/3T3) show that the obtained SG glasses and their extracts do not induce negative effects in cell viability. Finally, it was possible to employ SG BG_Ca/K glass to manufacture highly porous shell scaffolds, which remained almost amorphous. The obtained scaffolds were characterized by an open and fully interconnected porosity and by a compact and permeable external surface, which made them easy to handle (compression strength: 0.6$0.7 \mathrm{MPa}$ ). On the basis of these good outcomes, in the view of a potential application of the produced materials for bone tissue engineering, a full biological characterization is in progress to integrate the cytotoxicity

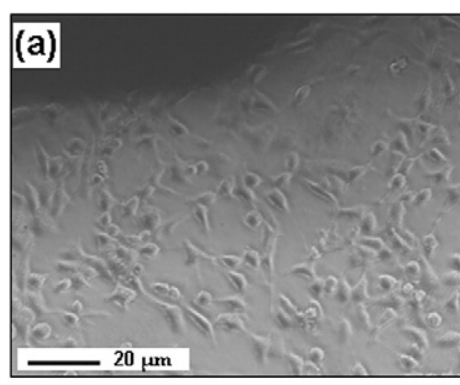

BG_Ca

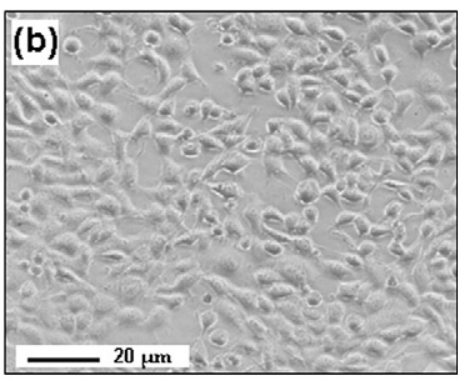

BG_Ca/Mix

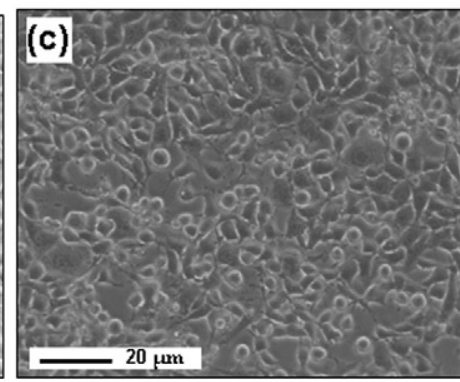

BG_Ca/K

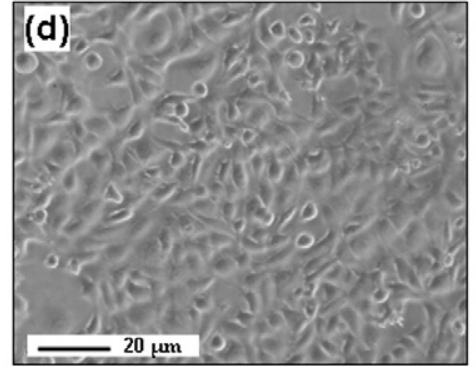

CTRL-

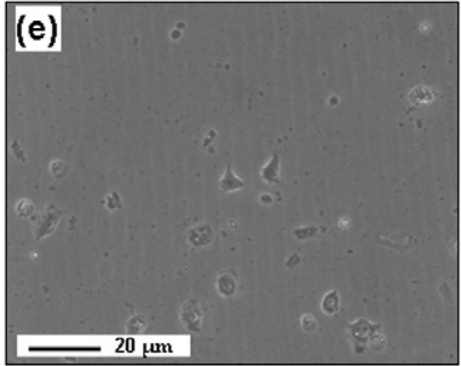

CTRL+

Fig. 16. Morphological evaluation of BALB/3T3 cells after $24 \mathrm{~h}$ direct contact with the samples using optical microscopy $140 \times$ magnification. 

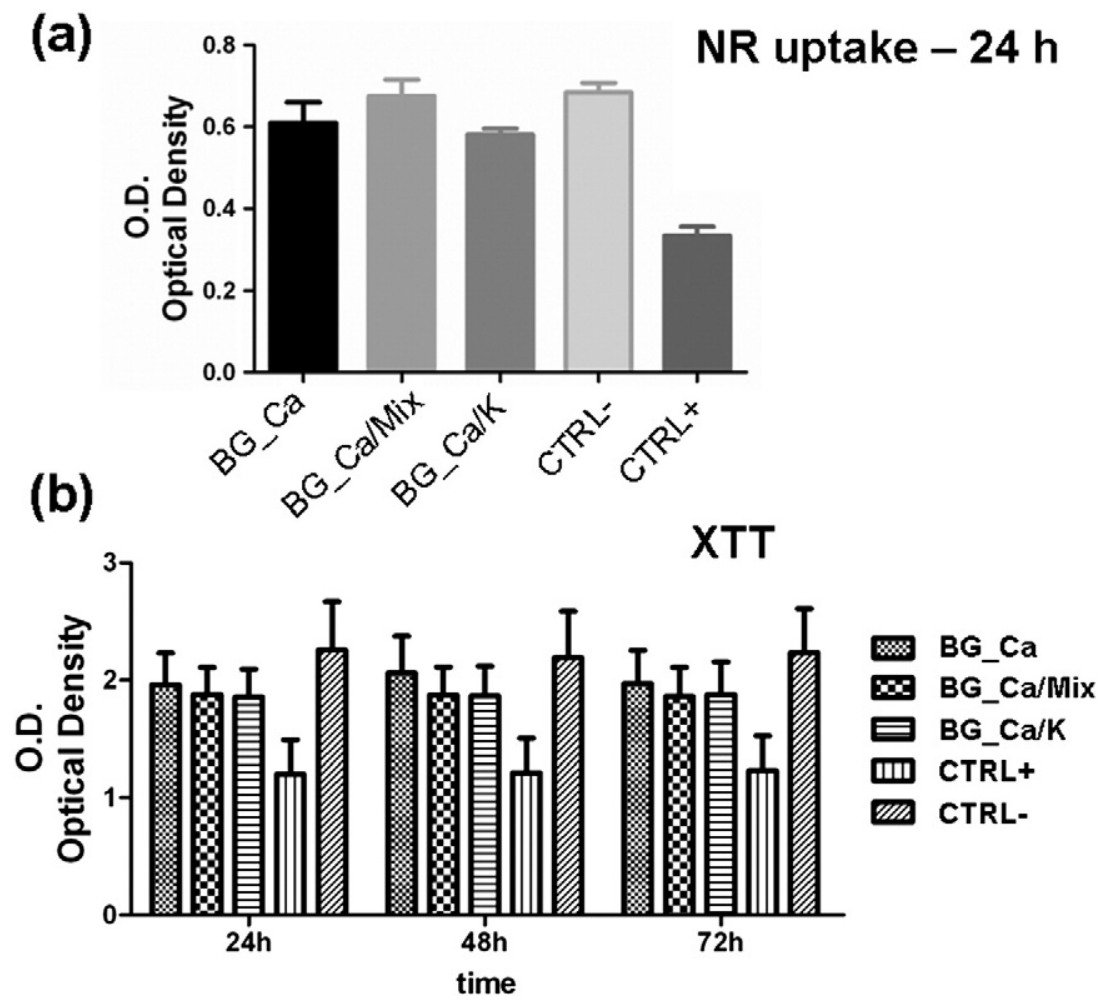

Fig. 17. (a) NR uptake after $24 \mathrm{~h}$ in the different samples and (b) XTT test results.

results presented here. Moreover, a deeper insight into the mechanical behavior of the obtained scaffolds could be of interest. These findings will be the subject of specific future works.

\section{References}

[1] L.L. Hench, The story of Bioglass ${ }^{\circledR}$, J. Mater. Sci. Mater. Med. 17 (2006) 967-978.

[2] L.L. Hench, Bioceramics: from concept to clinic, J. Am. Ceram. Soc. 74 (1991) 1487-1510.

[3] M. Bosetti, M. Cannas, The effect of bioactive glasses on bone marrow stromal cells differentiation, Biomaterials 26 (2005) 3873-3879.

[4] L.L. Hench, Genetic design of bioactive glass, J. Eur. Ceram. Soc. 29 (2009) 1257-1265.

[5] A. Hoppe, N.S. Güldal, A.R. Boccaccini, A review of the biological response to ionic dissolution products from bioactive glasses and glass-ceramics, Biomaterials 32 (2011) 2757-2774.

[6] L.L. Hench, J.K. West, The sol-gel process, Chem. Rev. 90 (1990) 33-72.

[7] L.L. Hench, Sol-gel materials for bioceramic applications, Curr. Opin. Solid State Mater. Sci. 2 (1997) 604-610.

[8] M.M. Pereira, L.L. Hench, Mechanisms of hydroxyapatite formation on porous gelsilica substrates, J. Sol-Gel Sci. Technol. 7 (1996) 59-68.

[9] J.P. Zhong, D.C. Greenspan, Processing and properties of sol-gel bioactive glasses, J. Biomed. Mater. Res. B Appl. Biomater. 53 (2000) 694-701.

[10] L.L. Hench, J.K. West, Biological applications of bioactive glasses, Life Chem Rep. 13 (1996) 187-241.

[11] R. Li, A.E. Clark, L.L. Hench, An investigation of bioactive glass powders by sol-gel processing, J. Appl. Biomater. 2 (1991) 231-239.

[12] M. Vallet-Regí, V.R. Rangel, A.J. Salinas, Glasses with medical applications, Eur. J. Inorg. Chem. 2003 (2003) 1029-1042.

[13] A. Balamurugan, G. Balossier, S. Kannan, J. Michel, A.H.S. Rebelo, J.M.F. Ferreira, Development and in vitro characterization of sol-gel derived $\mathrm{CaO}-\mathrm{P}_{2} \mathrm{O}_{5}-\mathrm{SiO}_{2}-\mathrm{ZnO}$ bioglass, Acta Biomater. 3 (2007) 255-262.

[14] A. Saboori, M. Rabiee, F. Moztarzadeh, M. Sheikhi, M. Tahriri, M. Karimi, Synthesis, characterization and in vitro bioactivity of sol-gel-derived $\mathrm{SiO}_{2}-\mathrm{CaO}-\mathrm{P}_{2} \mathrm{O}_{5}-\mathrm{MgO}$ bioglass, Mater. Sci. Eng. C 29 (2009) 335-340.

[15] A. Balamurugan, G. Balossier, D. Laurent-Maquin, S. Pina, A.H.S. Rebelo, J. Faure, J.M. F. Ferreira, An in vitro biological and anti-bacterial study on a sol-gel derived silverincorporated bioglass system, Dent. Mater. 24 (2008) 1343-1351.

[16] M. Brink, T. Turunen, R.P. Happonen, A. Yli-Urpo, Compositional dependence of bioactivity of glasses in the system $\mathrm{Na}_{2} \mathrm{O}-\mathrm{K}_{2} \mathrm{O}-\mathrm{MgO}-\mathrm{CaO}-\mathrm{B}_{2} \mathrm{O} 3-\mathrm{P}_{2} \mathrm{O}_{5}-\mathrm{SiO}_{2}$, J. Biomed. Mater. Res. 37 (1997) 114-121.

[17] Q.-Z. Chen, G.A. Thouas, Fabrication and characterization of sol-gel derived 45S5 Bioglass ${ }^{\circledR}$-ceramic scaffolds, Acta Biomater. 7 (2011) 3616-3626.
[18] M. Lombardi, L. Gremillard, J. Chevalier, L. Lefebvre, I. Cacciotti, A. Bianco, L. Montanaro, A comparative study between melt-derived and sol-gel synthesized 45S5 bioactive glasses, Key Eng. Mater. 541 (2013) 15-30.

[19] Q.Z. Chen, Y. Li, L.Y. Jin, J.M.W. Quinn, P.A. Komesaroff, A new sol-gel process for producing $\mathrm{Na}_{2} \mathrm{O}$-containing bioactive glass ceramics, Acta Biomater. 6 (2010) $4143-4153$.

[20] I. Cacciotti, M. Lombardi, A. Bianco, A. Ravaglioli, L. Montanaro, Sol-gel derived 45S5 bioglass: synthesis, microstructural evolution and thermal behaviour, J. Mater. Sci. Mater. Med. 23 (2012) 1849-1866.

[21] R.L. Siqueira, O. Peitl, E.D. Zanotto, Gel-derived $\mathrm{SiO}_{2}-\mathrm{CaO}-\mathrm{Na}_{2} \mathrm{O}-\mathrm{P}_{2} \mathrm{O}_{5}$ bioactive powders: synthesis and in vitro bioactivity, Mater. Sci. Eng. C 31 (2011) 983-991.

[22] Y. Hoshino, T. Utsunomiya, O. Abe, The thermal-decomposition of sodium nitrate and the effects of several oxides on the decomposition, Bull. Chem. Soc. Jpn. 54 (1981) 1385-1391.

[23] D.C. Clupper, L.L. Hench, Crystallization kinetics of tape cast bioactive glass 45S5, J. Non-Cryst. Solids 318 (2003) 43-48.

[24] D. Bellucci, V. Cannillo, A. Sola, An overview of the effects of thermal processing on bioactive glasses, Sci. Sinter. 42 (2010) 307-320.

[25] L. Lefebvre, J. Chevalier, L. Gremillard, R. Zenati, G. Thollet, D. Bernache-Assolant, A. Govin, Structural transformations of bioactive glass 4555 with thermal treatments, Acta Mater. 55 (2007) 3305-3313.

[26] P. Li, Q. Yang, F. Zhang, T. Kokubo, The effect of residual glassy phase in a bioactive glass-ceramic on the formation of its surface apatite layer in vitro, J. Mater. Sci. Mater. Med. 3 (1992) 452-456.

[27] D.C. Clupper, J.J. Mecholsky Jr., G.P. LaTorre, D.C. Greenspan, Bioactivity of tape cast and sintered bioactive glass-ceramic in simulated body fluid, Biomaterials 23 (2002) 2599-2606.

[28] L. Altomare, D. Bellucci, G. Bolelli, B. Bonferroni, V. Cannillo, L. De Nardo, R. Gadow, A. Killinger, L. Lusvarghi, A. Sola, N. Stiegler, Microstructure and in-vitro behaviour of 45S5 bioglass coatings deposited by high velocity suspension flame spraying (HVSFS), J. Mater. Sci. Mater. Med. 22 (2011) 1303-1319.

[29] Q.Z. Chen, I.D. Thompson, A.R. Boccaccini, 45S5 Bioglass ${ }^{\circledR}$-derived glass-ceramic scaffolds for bone tissue engineering, Biomaterials 27 (2006) 2414-2425.

[30] R. Ravarian, F. Moztarzadeh, H.M. Solati, S.M. Rabiee, P. Khoshakhlagh, M. Tahriri, Synthesis, characterization and bioactivity investigation of bioglass/hydroxyapatite composite, Ceram. Int. 36 (2010) 291-297.

[31] M.W.G. Lockyer, D. Holland, R. Dupree, NMR investigation of the structure of some bioactive and related glasses, J. Non-Cryst. Solids 188 (1995) 207-219.

[32] D. Bellucci, A. Sola, M. Gazzarri, F. Chiellini, V. Cannillo, A new hydroxyapatite-based biocomposite for bone replacement, Mater. Sci. Eng. C 33 (2013) 1091-1101.

[33] A. Sola, D. Bellucci, M.G. Raucci, S. Zeppetelli, L. Ambrosio, V. Cannillo, Heat treatment of $\mathrm{Na}_{2} \mathrm{O}-\mathrm{CaO}-\mathrm{P}_{2} \mathrm{O}_{5}-\mathrm{SiO}_{2}$ bioactive glasses: densification processes and postsintering bioactivity, J. Biomed. Mater. Res. A 100A (2012) 305-322.

[34] D. Bellucci, A. Sola, V. Cannillo, Low temperature sintering of innovative bioactive glasses, J. Am. Ceram. Soc. 95 (2012) 1313-1319. 
[35] D. Bellucci, A. Sola, V. Cannillo, Bioactive glass-based composites for the production of dense sintered bodies and porous scaffolds, Mater. Sci. Eng. C 33 (2013) $2138-2151$

[36] T. Kokubo, H. Takadama, How useful is SBF in predicting in vivo bone bioactivity? Biomaterials 27 (2006) 2907-2915.

[37] D. Bellucci, V. Cannillo, F. Chiellini, G. Ciardelli, M. Gazzarri, P. Gentile, A. Sola, Processing and characterization of innovative scaffolds for bone tissue engineering, J. Mater. Sci. Mater. Med. 23 (2012) 1397-1409.

[38] D. Bellucci, V. Cannillo, A. Sola, Shell scaffolds: a new approach towards high strength bioceramic scaffolds for bone regeneration, Mater. Lett. 64 (2010) 203-206.

[39] D. Bellucci, V. Cannillo, A. Sola, A new bioactive glass composition for bioceramic scaffolds, J. Ceram. Sci. Technol. 01 (2010) 33-40.

[40] C. Vitale-Brovarore, F. Baino, E. Verné, High strength bioactive glass-ceramic scaffolds for bone regeneration, J. Mater. Sci. Mater. Med. 20 (2009) 643-653.

[41] C. Vitale-Brovarone, M. Miola, C. Balagna, E. Verné, 3D-glass-ceramic scaffolds with antibacterial properties for bone grafting, Chem. Eng. J. 137 (2008) 129-136.

[42] T. Kokubo, H. Kushitani, S. Sakkc, T. Kitsugi, T. Yamamuro, Solutions able to reproduce in vivo surface-structure changes in bioactive glass-ceramic A-W, J. Biomed. Mater. Res. 24 (1990) 721-734.

[43] International Standard 10993-5, Biological Evaluation of Medical Devices - Part 5: Tests for Cytotoxicity: In Vitro Methods, 2009.

[44] International Standard 10993-12, Biological Evaluation of Medical Devices - Part 12: Sample Preparation and Reference Materials, 2007.

[45] G. Repetto, A. del Peso, J.L. Zurita, Neutral red uptake assay for the estimation of cell viability/cytotoxicity, Nat. Protoc. 3 (2008) 1125-1131.

[46] N.W. Roehm, G.H. Rodgers, S.M. Hatfield, A.L. Glasebrook, An improved colorimetric assay for cell proliferation and viability utilizing the tetrazolium salt XTT, J. Immunol. Methods 142 (1991) 257-265.

[47] M.V. Berridge, P.M. Herst, A.S. Tan, Tetrazolium dyes as tools in cell biology: new insights into their cellular reduction, Biotechnol. Annu. Rev. 11 (2005) 127-152.

[48] I. Izquierdo-Barba, A.J. Salinas, M. Vallet-Regí, In vitro calcium phosphate layer formation on sol-gel glasses of the $\mathrm{CaO}-\mathrm{SiO}_{2}$ system, J. Biomed. Mater. Res. 47 (1999) 243-250.

[49] A. Oki, B. Parveen, S. Hossain, S. Adeniji, H. Donahue, Preparation and in vitro bioactivity of zinc containing sol-gel-derived bioglass materials, J. Biomed. Mater. Res. 69 (2004) 216-221.

[50] E.S. Freeman, The kinetics of the thermal decomposition of potassium nitrate and of the reaction between potassium nitrite and oxygen, J. Am. Chem. Soc. 79 (1957) 838-842.

[51] J.R. Jones, L.M. Ehrenfried, L.L. Hench, Optimising bioactive glass scaffolds for bone tissue engineering, Biomaterials 27 (2006) 964-973.

[52] A.S. Rizkalla, D.W. Jones, D.B. Clarke, G.C. Hall, Crystallization of experimental bioactive glass compositions, J. Biomed. Mater. Res. 32 (1996) 119-124.

[53] X. Liu, C. Ding, P.K. Chu, Mechanism of apatite formation on wollastonite coatings in simulated body fluids, Biomaterials 25 (2004) 1755-1761.

[54] P.N. De Aza, F. Guitian, S. De Aza, Bioactivity of wollastonite ceramics: in vitro evaluation, Scr. Metall. Mater. 31 (1994) 1001-1005.

[55] P.N. De Aza, Z. Luklinska, M.R. Anseau, F. Guitian, S. De Aza, Morphological studies of pseudowollastonite for biomedical application, J. Microsc. 182 (1996) 24-31.

[56] D. Bellucci, A. Sola, P. Gentile, G. Ciardelli, V. Cannillo, Biomimetic coating on bioactive glass-derived scaffolds mimicking bone tissue, J. Biomed. Mater. Res. A 100A (2012) 3259-3266.

[57] E. Landi, G. Celotti, G. Logroscino, A. Tampieri, Carbonated hydroxyapatite as bone substitute, J. Eur. Ceram. Soc. 23 (2003) 2931-2937.

[58] Z. Schwarts, B.D. Boyan, Underlying mechanisms at the bone-biomaterial interface, J. Cell. Biochem. 56 (1994) 340-347.
[59] O. Bretcanu, Q. Chen, S.K. Misra, A.R. Boccaccini, E. Verné, C. Vitale-Brovarone, Biodegradable polymer coated $45 \mathrm{~S} 5$ bioglass-derived glass-ceramic scaffolds for bone tissue engineering, Glass Technol. Eur. J. Glass Sci. Technol. Part A 48 (2007) 227-234

[60] Q.Z. Chen, A.R. Boccaccini, Poly(D, L-lactic acid) coated 45S5 Bioglass ${ }^{\circledR}$-based scaffolds: processing and characterization, J. Biomed. Mater. Res. A 77 (2006) 445-457.

[61] H. Follet, K. Bruyère-Garnier, F. Peyrin, J.P. Roux, M.E. Arlot, B. Burt-Pichat, C. Rumelhart, P.J. Meunier, Relationship between compressive properties of human os calcis cancellous bone and microarchitecture assessed from 2D and 3D synchrotron microtomography, Bone 36 (2005) 340-351.

[62] T.M. Keaveny, E.F. Morgan, O.C. Yeh, Bone mechanics, in: M. Kutz (Ed.), Standard Handbook of Biomedical Engineering and Design, McGraw Hill, New York, 2003, pp. 8.1-8.23.

[63] M. Bohner, J. Lemaître, Can bioactivity be tested in vitro with SBF solution? Biomaterials 30 (2009) 2175-2179.

[64] S. Kotani, Y. Fujita, T. Kitsugi, T. Nakamura, T. Yamamuro, C. Ohtsuki, T. Kokubo, Bone bonding mechanism of $\beta$-tricalcium phosphate, J. Biomed. Mater. Res. 25 (1991) 1303-1315.

[65] D. Apelt, F. Theiss, A.O. El-Warrak, K. Zlinszky, R. Bettschart-Wolfisberger, M Bohner, S. Matter, J.A. Auer, B. von Rechenberg, In vivo behavior of three different injectable hydraulic calcium phosphate cements, Biomaterials 25 (2004) 1439-1445.

[66] C. Vitale-Brovarone, E. Verné, P. Appendino, Macroporous bioactive glass-ceramic scaffolds for tissue engineering, J. Mater. Sci. Mater. Med. 17 (2006) 1069-1078.

[67] S.V. Dorozhkin, Calcium orthophosphates in nature, biology and medicine, Materials 2 (2009) 399-498.

[68] J.R. Jones, P. Sepulveda, L.L. Hench, Dose-dependent behaviour of bioactive glass dissolution, J. Biomed. Mater. Res. 58 (2001) 720-726.

[69] S. Padilla, J. Román, S. Sánchez-Salcedo, M. Vallet-Regí, Hydroxyapatite/ $\mathrm{SiO}_{2}-\mathrm{CaO}$ $\mathrm{P}_{2} \mathrm{O}_{5}$ glass materials: in vitro bioactivity and biocompatibility, Acta Biomater. 2 (2006) 331-342.

[70] O. Peitl, E. Zanotto, L.L. Hench, Highly bioactive $\mathrm{P}_{2} \mathrm{O}_{5}-\mathrm{Na}_{2} \mathrm{O}-\mathrm{CaO}-\mathrm{SiO}_{2}$ glass-ceramics, J. Non-Cryst. Solids 292 (2001) 115-126.

[71] T. Kokubo, H.M. Kim, M. Kawashita, Novel bioactive materials with different mechanical properties, Biomaterials 24 (2003) 2161-2175.

[72] Z. Zhou, J. Ruan, J. Zou, Z. Zhou, Preparation and bioactivity of sol-gel macroporous bioactive glass, J. Univ. Sci. Technol. Beijing 15 (2008) 290-296.

[73] Q. Fu, M.N. Rahaman, B.S. Bal, R.F. Brown, D.E. Day, Mechanical and in vitro performance of 13-93 bioactive glass scaffolds prepared by a polymer foam replication technique, Acta Biomater. 4 (2008) 1854-1864.

[74] A. Antonakosa, E. Liarokapisa, T. Leventouri, Micro-Raman and FTIR studies of synthetic and natural apatites, Biomaterials 28 (2007) 3043-3054.

[75] D. Bellucci, G. Bolelli, V. Cannillo, A. Cattini, A. Sola, In situ Raman spectroscopy investigation of bioactive glass reactivity: simulated body fluid solution vs TRISbuffered solution, Mater. Charact. 62 (2011) 1021-1028.

[76] A. Awonusi, M.D. Morris, M.M.J. Tecklenburg, Carbonate assignment and calibration in the Raman spectrum of apatite, Calcif. Tissue Int. 81 (2007) 46-52.

[77] K.D. Paull, R.H. Shoemaker, M.R. Boyd, et al., The synthesis of XTT: a new tetrazolium reagent that is bioreducible to a water-soluble formazan, J. Heterocycl. Chem. 25 (1988) 911-914.

[78] C.J. Goodwin, S.J. Holt, S. Downes, N.J. Marshall, Microculture tetrazolium assays: a comparison between two new tetrazolium salts, XTT and MTS, J. Immunol. Methods 13 (1995) 95-103.

[79] L. Huyck, C. Ampe, M. Van Troys, The XTT cell proliferation assay applied to cell layers embedded in three-dimensional matrix, Assay Drug Dev. Technol. 10 (2012) 382-392. 